\title{
Antioxidant and antimicrobial activities of Lavandula angustifolia Mill. field-grown and propagated in vitro
}

\author{
Dominika Andrys ${ }^{1 *}$, Danuta Kulpa ${ }^{1}$, Monika Grzeszczuk', \\ Magdalena Bihun', Agnieszka Dobrowolska ${ }^{2}$
}

\author{
${ }^{1}$ Department of Plant Genetics, Breeding and Biotechnology \\ ${ }^{2}$ Department of Horticulture \\ Faculty of Environmental Management and Agriculture, West Pomeranian University of Technology \\ Słowackiego 17, 71-434 Szczecin, \\ ${ }^{3}$ Molecular Biology and Biotechnology Centre, Laboratory of Environmental Research \\ University of Szczecin, Małkocin 37, 73-110 Stargard
}

\begin{abstract}
In the study, micropropagation of three varieties of Lavandula angustifolia was developed, and the appearance of trichomes, antioxidant activity of extracts and antimicrobial activity of essential oils isolated from plants growing in field conditions and in vitro cultures were compared. The study evaluated the number of shoots, and the height and weight of the plants grown on media with additions of BAP, KIN and 2iP. The greatest height was attained by the lavenders growing on MS medium with the addition of $1 \mathrm{mg} \mathrm{dm}^{-3} 2 \mathrm{iP}$ - 'Ellagance Purple'. The greatest number of shoots was developed by the 'Ellagance Purple' and 'Munstead' plants growing on the medium with $2 \mathrm{mg} \mathrm{dm}^{-3}$ BAP. The highest weight was attained by the plants growing on the medium with the highest concentration of BAP -3 and $5 \mathrm{mg} \mathrm{dm}^{-3}$. Moreover, the present study determined the influence of media with the addition of different concentrations of IBA and media with a variable mineral composition $(1 / 2,1 / 4$, and complete composition of MS medium) and with the addition of IBA or NAA for rooting. The majority of the media used had a positive influence on the development of the root system. The longest root system was observed in 'Ellagance Purple' growing on the medium composed of $1 / 4 \mathrm{MS}$ with $0.2 \mathrm{mg} \mathrm{dm}^{-3}$ NAA. All the examined oils exhibited activity towards $S$. aureus, S. epidermidis, $P$. aeruginosa, E. coli and C. albicans. The majority of the essential oils isolated from the plants propagated in vitro exhibited stronger antimicrobial activity than the field-grown plants. The plants propagated under in vitro conditions demonstrated considerably higher antioxidant activity as compared with the field-grown plants, which was determined using the DPPH, FRAP and ABTS assay.
\end{abstract}

Key words: ABTS, Blue River, DPPH, essential oils, FRAP, Munstead, plant tissue culture

\begin{abstract}
Abbreviations:
$2 \mathrm{iP}-6$ - $(\gamma, \gamma$-dimethylallylamino) purine, ABTS - determination of free radical-scavenging ability by the use of a stable ABTS radical cation, BA, BAP - 6-benzyloaminopurine, BR - 'Blue River', DPPH - determination of DPPH radical scavenging capacity, EP - 'Ellagance Purple', FRAP - determination of ferric reducing antioxidant power, GAE - gallic acid, IAA - indole-3-acetic acid, IBA - indole-3-butyric acid, KIN - kinetin, LSD - least significant difference, M - 'Munstead', MS - Murashige and Skoog medium, NAA - 1-naphthaleneacetic acid, TAA - total antioxidant activity, TE - trolox, 6-hydroxy-2,5,7,8-tetramethylchromane-2-carboxylic acid
\end{abstract}

\footnotetext{
*Corresponding author.

Tel.: +91 44961 95;

e-mail: dominika.andrys@zut.edu.pl (D. Andrys).
} 


\section{INTRODUCTION}

The genus Lavandula belongs to the Lamiaceae Lindl., Labiatae Juss. family, and it includes approximately 39 species (Upson and Andrews 2004). The natural distribution area for lavender is the Mediterranean (Basch et al. 2004), as well as the Canary Islands and India (Upson and Andrews 2004, Verma et al. 2010). Native species of the genus can also be found in northern, eastern and southern Africa, Bulgaria, Spain, Poland, Turkey, France, England, Russia, Australia and the USA (Śmigielski et al. 2009, Kara and Baydar 2013). The genus Lavandula represents one of the most popular ornamental and medicinal plants (Lis-Balchin and Hart 1997, Ghelardini et al. 1999, Lis-Balchin and Hart 1999, Woronuk et al. 2011). The best-known species of the genus Lavandula include L. stoechas, $L$. dentata and $L$. angustifolia, the last of them also referred to as L. officinalis.

Lavender has a long history as a medicinal product. In vitro tests have demonstrated that lavender oil has analgesic (Silva et al. 2015) and anaesthetic effects (Ghelardini et al. 1999). Lavender scent in the room prevents deterioration in work performance (Sakamoto et al. 2005), may improve memory and the health state of people with Alzheimer's disease (Adsersen et al. 2006). Lavender essential oil helps treat diseases of the digestive tract; it exhibits a diastolic effect for the ileum and smooth muscles (Lis-Balchin and Hart 1997). Thus far, antimicrobial (Cavanagh and Wilkinson 2002, Adaszyńska et al. 2013), antifungal (Moon et al. 2007) and antioxidant (Spiridon et al. 2011) activities of the essential oils isolated from field-grown plants have been confirmed.

Essential oils constitute mixtures of volatile compounds, primarily monoterpenes and sesquiterpenes (Landmann et al. 2007, Mahmoudi and Nosratpour 2013, Akbar et al. 2014). The main components of the essential oils from $L$. angustifolia are, among others, linalool, linalool acetate, geraniol, and borneol (Cong et al. 2008, Demissie et al. 2011, Prasad et al. 2015). The composition of an essential oil depends mainly on the plant genotype, yet its composition may differ under the influence of developmental and environmental factors, e.g. exposure to the sun, plant age, seedling collection method, or essential oil isolation method (Verma et al. 2010, Hamad et al. 2013, Wesołowska et al. 2015a, 2015b).

A method allowing the obtaining of a large amount of plant tissues in order to isolate essential oils from them is the in vitro tissue culture method. Thus far, several attempts have been made to propagate Lavandula plants in vitro, e.g. such species as: L. dentata (Sudriá et al. 1999, Sudriá et al. 2001), L. pedunculata (Zuzarte et al. 2010), L. viridis (Nogueira and Romano 2002), and L. angustifolia (Falk et al. 2009). However, the antimicrobial and antioxidant properties of the essential oils isolated from them have not been determined. In a study conducted by Andrys and Kulpa (2017), it was found that the composition and the amount of oils isolated from tissues of plants propagated in vitro differed from those of the oils isolated from fieldgrown plants, which might have an influence on their antioxidant and antimicrobial activities. As indicated by an antimicrobial study in relation to essential oils of in vitro Salvia przewalskii (Skała et al. 2007), and in relation to ethanol extracts of in vitro Syzygium cumini (Vidwans et al. 2015), and also by an antioxidant study of in vitro Curcuma aromatica essential oils (Mohanty et al. 2015), the activity of isolates from in vitro plants is different and usually higher in comparison with plants growing in field conditions.

Essential oils with elevated antimicrobial and antioxidant activities, isolated from plants growing in in vitro conditions may be used for the preservation of cosmetics and to prolong their shelf life. Currently, the majority of preservatives used by the cosmetics industry are artificially synthesized chemical compounds. Preservatives such as: phenoxyethanol, benzyl alcohol, dehydroacetic acid or parabens have a negative impact on human skin and a possible carcinogenic effect (Darbre et al. 2004). The preservatives mentioned have been approved by the FDA (Food and Drug Administration) of the USA, and by the Regulation of the European Parliament and the European Commission (EC) no. 1223/2009 in the European Union, yet they cannot exceed $1 \%$ of product's volume for phenoxyethanol and benzyl alcohol, and $0.6 \%$ for dehydroacetic acid. Therefore, new, natural preservatives are searched for as an alternative to the artificial and synthetic preservatives. Due to the expected high biological activity of essential oils, artificial preservatives that are strongly allergenic, irritating and undesirable substances would not have to be added to cosmetics.

The present study aimed to develop an efficient method for the propagation of three L. angustifolia cultivars in vitro in order to obtain a large amount of plant tissue, and to compare the antioxidant activity of dried plant material and antimicrobial activity of 
essential oils isolated from field-grown and in vitro plants. Moreover, the morphology of the secretory organs, such as trichomes, which produce essential oils, was compared.

\section{MATERIAL AND METHODS}

\section{Plant material and in vitro conditions}

The material for the establishment of in vitro cultures consisted of 1-year-old plants of three L. angustifolia cultivars: Munstead, Ellagance Purple and Blue River, grown in an experimental field of the Department of Horticulture at the West Pomeranian University of Technology in Szczecin. The study material for the determination of antioxidant activity, polyphenol content and for the isolation of essential oils to determine their antimicrobial activity. as well as for microscopic examination consisted of the shoots together with the inflorescence leaves of the same field-grown plants and from plants propagated in vitro on MS (Murashige and Skoog 1962) medium enriched with $2 \mathrm{mg} \mathrm{dm}^{-3} \mathrm{KIN}$ (kinetin) and $0.2 \mathrm{mg} \mathrm{dm}^{-3} \mathrm{IAA}$ (indole-3-acetic acid).

For the establishment of the cultures, $1-2 \mathrm{~cm}$ long shoot fragments were used, which were rinsed under running water for $15 \mathrm{~min}$., then immersed in $70 \% \mathrm{EtOH}$ for 30 seconds, and subsequently in $7 \%$ sodium hypochlorite $(\mathrm{NaOCl})$ for $20 \mathrm{~min}$. The disinfected fragments were rinsed with sterile $\mathrm{dd}_{2} \mathrm{O}$ three times, dried on a sterile filter paper, and placed in $200 \mathrm{ml}$ jars, each of which contained 20 $\mathrm{ml}$ of MS medium enriched with $0.1 \mathrm{mg} \mathrm{dm}^{-3} \mathrm{KIN}$ and $0.01 \mathrm{mg} \mathrm{dm}^{-3}$ IAA. At all the stages of the study, use was made of the basal MS medium (Murashige and Skoog 1962) supplemented with vitamins: $0.5 \mathrm{mg} \mathrm{dm}^{-3}$ nicotinic acid, $0.5 \mathrm{mg} \mathrm{dm}^{-3}$ pyridoxine $\mathrm{HCl}, 0.1 \mathrm{mg} \mathrm{dm}^{-3}$ thiamine $\mathrm{HCl}, 2 \mathrm{mg} \mathrm{dm}^{-3}$ glycine, $30 \mathrm{~g} \mathrm{dm}^{-3}$ sucrose, $100 \mathrm{mg} \mathrm{dm}^{-3}$ inositol, and $7 \mathrm{~g}$ $\mathrm{dm}^{-3}$ agar. The control medium at all the stages of the study was the MS medium without the addition of plant growth regulators. The $\mathrm{pH}$ of the medium was established at 5.7 using $0.1 \mathrm{M}$ solutions of $\mathrm{HCl}$ and $\mathrm{NaOH}$, and it was sterilized in an autoclave at $121^{\circ} \mathrm{C}$ for $20 \mathrm{~min}$. A single explant was placed on each medium in 50 repetitions. After introducing the plant fragments, the jars were placed in a growth chamber for 14 days at a temperature of $23 \pm 1^{\circ} \mathrm{C}$. The cultures were illuminated with fluorescent light with an intensity of 40 PAR $\left(\mu \mathrm{E} \mathrm{m}^{-2} \mathrm{~s}^{-1}\right)$ for $16 \mathrm{~h}$ a day. After 14 days of culture, the explants which initiated growth were selected for further studies.

\section{Propagation stage}

The explants which initiated growth were passaged onto the MS medium 2 times. From this baseline population, plant fragments were obtained and divided into single-node shoot fragments. MS media with the addition of BAP (6-benzyloaminopurine), KIN or $2 \mathrm{iP}$ (6-( $\gamma, \gamma$-dimethylallylamino) purine) in the amount from 0.5 to $5 \mathrm{mg} \mathrm{dm}^{-3}$ were used. Eight explants were introduced into each jar in 20 repetitions. The propagation stage lasted 6 weeks.

\section{Rooting stage}

In the first experiment, single-node shoot fragments were placed on the MS medium supplemented with IBA (indole-3-butyric acid) in a concentration from $0.05 \mathrm{mg} \mathrm{dm}^{-3}$ to $1.75 \mathrm{mg} \mathrm{dm}^{-3}$. In the subsequent experiment, lavender fragments were placed on the media with $1 / 2,1 / 4$ and full MS mineral composition with the addition of $0.2 \mathrm{mg} \mathrm{dm}{ }^{-3}$ IBA or NAA (1-naphthaleneacetic acid). Eight explants were introduced into each jar in 20 repetitions. The rooting stage lasted 4 weeks.

\section{Micromorphological analysis}

Leaves of narrow-leaved lavender plants growing in field conditions and in vitro were subjected to a micromorphological analysis with the use of a scanning electron microscope (SEM). Fresh leaves were cut from a stalk and mounted on SEM stubs and stored in a desiccator with silica gel until dry. The material was dried in a Quorum Technologies Critical Point Dryer, then sprayed with a gold layer in a Quorum Technologies Sputter Coater. Observations were conducted using a Carl Zeiss EVO LS 10 SEM with an accelerating voltage of 1 or $15 \mathrm{kV}$. The diameter of trichomes and their number on both adaxial and abaxial surfaces of the leaf was determined in field-grown and in vitro propagated plants.

\section{Antimicrobial activity of essential oils}

Essential oils were isolated from field-grown and in vitro propagated plants using the hydrodistillation method in the Deryng apparatus in accordance with the European Pharmacopoeia (2014). $20 \mathrm{~g}$ of air-dry plant tissue dried at $30^{\circ} \mathrm{C}$ was treated with distilled water and heated to boiling temperature, then left to cool down. Then, the distillate isolated in the condenser was dried using anhydrous sodium sulfate (VI). The thus obtained essential oil was used for further study. The disc diffusion method was used to evaluate the antimicrobial activity. The activity was determined for the bacteria Escherichia coli (ATCC 8739), Pseudomonas aeruginosa 
(ATCC 9027), Staphylococcus aureus (ATCC 6538), Staphylococcus epidermidis (ATCC 12228), and the fungi Candida albicans (ATCC 10231). The positive control consisted of nystatin (C. albicans), piperacillin (E. coli and $P$. aeruginosa), cefoxitin (S. aureus and $S$. epidermidis) and $96 \% \mathrm{EtOH}$. DMSO constituted the negative control. Mueller Hinton media were inoculated with $100 \mu 1$ of bacteria (106 CFU/ml). Filter paper discs (diameter $6 \mathrm{~mm}$ ) were soaked for 1-2 min. with $10 \mu \mathrm{l}$ of essential oil at $100 \%$ concentration and immediately transferred symmetrically onto the inoculated plate. The plates were incubated at $37^{\circ} \mathrm{C}$ for $24 \mathrm{~h}$ (bacteria), or $48 \mathrm{~h}$ (C. albicans), then readout was performed. Zones of growth inhibition were measured (as diameter given in millimeters). The analyses were performed in three repetitions.

\section{Preparation of plant extracts}

The material for the study consisted of dried narrow-leaved lavender plants grown in the field and propagated in vitro. The preparation of plant extracts for antioxidant property analysis and total polyphenol content was performed using the method proposed by Wojdyło et al. (2007) with some modifications. Dried lavender herb samples were ground using a laboratory mill. The ground dry plant material $(1 \mathrm{~g})$ was treated with $80 \%$ aqueous methanol $(\mathrm{MeOH})$ to $100 \mathrm{ml}$ volume. The mixtures were placed in an ultrasonic bath at room temperature and sonicated continuously for two periods: 10 and 15 minutes, and then left for 24 hours at room temperature. The obtained extracts were filtered through Whatman No. 1 filter paper. The filtrates were diluted 10 times with $80 \% \mathrm{MeOH}$ and then centrifuged at $1500 \mathrm{rpm}$ for 10 minutes. All the extractions were carried out in three replicates. The extracts were kept at $4{ }^{\circ} \mathrm{C}$ and used for analyses within 24 hours. The thus obtained extracts were used to determine the polyphenol content and antioxidant activity using the DPPH, FRAP and ABTS methods.

\section{Determination of total polyphenol content}

Total polyphenol content was determined spectrophotometrically using the Folin-Ciocalteu colorimetric method as described by Wojdyło et al. (2007) with some modifications (Akbar et al. 2014, Mahmoudi and Nosratpour 2013). Plant extract $(100 \mu \mathrm{l})$ was mixed with $0.2 \mathrm{ml}$ of the FolinCiocalteu reagent, $2 \mathrm{ml}$ of distilled water and $1 \mathrm{ml}$ of $20 \%$ sodium carbonate. The samples were allowed to stand for 1 hour at room temperature in darkness. Then absorbance was measured at
$760 \mathrm{~nm}$. Gallic acid (GAE) was used to calculate the standard curve, and the results were expressed as GAE milligrams per $g$ of dry weight (DW).

\section{Determination of DPPH radical scavenging capacity}

The DPPH (2,2-diphenyl-1-picrylhydrazyl) radical scavenging capacity was evaluated according to the procedure of Kumaran and Karunakaran (2007), and Wojdyło et al. (2007). DPPH (0.3 mM) was dissolved in pure ethanol (99.8\%). Plant extract $(1 \mathrm{ml})$ or $1 \mathrm{ml}$ of $80 \% \mathrm{MeOH}$ (control) was added to $3 \mathrm{ml}$ of pure ethanol (EtOH) and $1 \mathrm{ml}$ of the DPPH solution. The samples were incubated at room temperature for 10 minutes in the dark. The reduction of the DPPH radical was determined spectrophotometrically by measuring absorption at $517 \mathrm{~nm}$. The percentage of DPPH scavenging activity was calculated using the equation: $\left[A_{0}-A_{1} / A_{0}\right] \times 100$, where $A_{0}$ is the absorbance of the control, and $\mathrm{A}_{1}$ is the absorbance of the extract. Moreover, trolox (TE, 6-hydroxy2,5,7,8-tetramethylchromane-2-carboxylic acid) was used to calibrate the standard curve, and the results were expressed as $\mathrm{mg}$ of trolox equivalent antioxidant capacity per $1 \mathrm{~g}$ of dry weight sample (mg TE g ${ }^{-1} \mathrm{DW}$ ).

\section{Determination of ferric reducing antioxidant power (FRAP)}

The total antioxidant potential of the samples was determined using the ferric reducing ability of plasma FRAP assay by Wojdyło et al. (2007) as a measure of antioxidant power. FRAP reagent was prepared by mixing acetate buffer $(300 \mathrm{mM}$, $\mathrm{pH}$ 3.6), a solution of $10 \mathrm{mM}$ TPTZ (2,4,6-tris(2pyridyl)-s-triazine) in $40 \mathrm{mM} \mathrm{HCl}$, and $20 \mathrm{mM}$ $\mathrm{FeCl}_{3} \cdot 6 \mathrm{H}_{2} \mathrm{O}$ (iron(III) chloride hexahydrate) at 10:1:1 ( $\mathrm{v} / \mathrm{v} / \mathrm{v})$, and warmed at $37^{\circ} \mathrm{C}$ before use. For the spectrophotometric assay, $2.7 \mathrm{ml}$ of the reagent and $0.3 \mathrm{ml}$ of the sample solution were mixed. The absorbance was taken at $593 \mathrm{~nm}$ after 4 minutes. The standard curve was prepared using different concentrations of trolox. The results were expressed in mg TE per g DW.

\section{Determination of free radical-scavenging ability by the use of a stable ABTS radical cation}

The free radical-scavenging activity was determined by ABTS radical cation decolorization procedures described by Re et al. (1999), Chew et al. (2011) and Wojdyło et al. (2007) with some modifications. ABTS (2,2'-azino-bis(3-ethylbenzothiazoline-6sulfonic acid) diammonium salt was dissolved in distilled water to a $7 \mathrm{mM}$ concentration. ABTS 
radical cation $\left(\mathrm{ABTS}^{\cdot+}\right)$ was produced by reacting ABTS stock solution with $2.45 \mathrm{mM}$ potassium peroxodisulfate and kept in the dark at room temperature for $16 \mathrm{~h}$ before use. The $\mathrm{ABTS}^{++}$ solution was diluted with PBS (phosphate buffered saline, $\mathrm{pH}$ 7.4) until its absorbance was equilibrated to $0.7( \pm 0.02)$ at $734 \mathrm{~nm}$ before usage. After the addition of $3.0 \mathrm{ml}$ of diluted $\mathrm{ABTS}{ }^{\cdot+}$ solution $\left(\mathrm{A}_{734}\right.$ $=0.7 \pm 0.02$ ) to $300 \mu 1$ of methanolic plant extracts, the absorbance reading was exactly $6 \mathrm{~min}$. after the initial mixing. Trolox was used for calibrating the standard curve, and the results were expressed as mg TE per $1 \mathrm{~g}$ of sample dry weight. Moreover, the percentage of ABTS radical scavenging capacity (Total Antioxidant Activity, TAA\%) was calculated using the formula: $\left[1-\left(\mathrm{A}_{\mathrm{s}} / \mathrm{A}_{\mathrm{c}}\right)\right] \cdot 100\left(\mathrm{~A}_{\mathrm{s}}-\right.$ absorbance of plant extract; $A_{c}-$ absorbance of control).

\section{Statistical analysis}

All the experiments, except the determination of antimicrobial activity of essential oils, were set up in a two-factor completely randomised design. The original percentage data from the rooting stages were transformed by arcsine transformation $\left(y^{\prime}=\arcsin y^{1 / 2}, y=\right.$ original percentage $\left./ 100\right)$. The significance of differences was determined by analysis of variance (ANOVA) and the Tukey t-test at $p=0.05$. The results obtained for antimicrobial activity were statistically analyzed using analysis of variance for 1-way cross-classification.

\section{RESULTS AND DISCUSSION}

\section{Initiation stage}

In the present study, the starting material were fragments of shoots of lavender plants, which were placed onto MS medium supplemented with $0.1 \mathrm{mg}$ $\mathrm{dm}^{-3} \mathrm{KIN}$ and $0.01 \mathrm{mg} \mathrm{dm}^{-3} \mathrm{IAA}$, on which growth was initiated in $90 \%$ of the explants placed.

\section{Propagation stage}

The present study determined the influence of cytokinins: BAP, KIN and $2 \mathrm{iP}$ in concentrations from 0.5 to $5 \mathrm{mg} \mathrm{dm}^{-3}$ added to media with the composition according to Murashige and Skoog (1962), on the height, number and weight of shoots. The cytokinins used: BAP $\left(0.5-5 \mathrm{mg} \mathrm{dm}^{-3}\right)$, 2 iP $\left(0.5-5 \mathrm{mg} \mathrm{dm}^{-3}\right)$ and KIN (2-5 $\left.\mathrm{mg} \mathrm{dm}^{-3}\right)$ had a positive influence on the development of plants of all the cultivars - the plants were taller and were characterized by greater weight in comparison with the control (Tab. 1). The strongest influence on growth was exerted by the media supplemented with $1.0 \mathrm{mg} \mathrm{dm}^{-3} 2$ iP for plants of 'Ellagance Purple'
(3.9 $\mathrm{cm})$, and $2.0 \mathrm{mg} \mathrm{dm}^{-3}$ BAP for 'Munstead' $(3.6 \mathrm{~cm})$. The medium without the addition of growth regulators had the strongest influence on the growth of 'Blue River' $(3.9 \mathrm{~cm})$. The media promoting the greatest weight gain were those supplemented with $5.0 \mathrm{mg} \mathrm{dm}^{-3} \mathrm{BAP}$ for 'Ellagance Purple' (1.3 g) and 'Munstead' $(1.0 \mathrm{~g})$, and $3.0 \mathrm{mg}$ $\mathrm{dm}^{-3}$ BAP for 'Blue River' $(1.0 \mathrm{~g})$.

For the propagation of $L$. angustifolia, Kumar et al. (2015) used MS medium with 4 combinations of BAP concentrations $\left(0.5,1,2\right.$ and $\left.1 \mathrm{mg} \mathrm{dm}^{-3}\right)$ and the respective concentrations of IAA $(0.5,0.5 .0 .5$ and $1 \mathrm{mg} \mathrm{dm}^{-3}$ ). The medium inducing the best propagation of the plants and the highest number of shoots was that supplemented with $2 \mathrm{mg} \mathrm{dm}^{-3}$ BAP and $0.5 \mathrm{mg} \mathrm{dm}^{-3}$ IAA. Al-Bakhit et al. (2007), too, had tested the combinations of cytokinin with auxin. They observed that the use of KIN in a concentration of $1.5 \mathrm{mg} \mathrm{dm}^{-3}$ combined with NAA in a concentration of $0.05 \mathrm{mg} \mathrm{dm}^{-3}$ at the same time stimulated the growth, weight gain and number of shoots in L. angustifolia. On the other hand, Jordan et al. (1998) had observed that the propagation of L. dentata plants was influenced by the concentration of cytokinin in the initial stage of cultures. Subculture considerably decreases the final number of shoots on the node segments of the isolated shoots, increasing in the presence of $2.0 \mu \mathrm{M}$ BA or $40.0 \mu \mathrm{M}$ KIN. It has been observed that the best multiplication efficiency is shown by plants growing on a medium containing $5.0 \mu \mathrm{M}$ BA or $20 \mu \mathrm{M}$ KIN.

The growth regulators used in the study: BAP and $2 \mathrm{iP}$ in a concentration of $0.5-5 \mathrm{mg} \mathrm{dm}^{-3}$ and KIN at $1-5 \mathrm{mg} \mathrm{dm}^{-3}$ had a positive influence on the number of shoots, which was considerably higher for all the tested cultivars in comparison with the control. The media influencing the formation of the greatest number of shoots were the MS-based media supplemented with $1.0 \mathrm{mg} \mathrm{dm}^{-3} 2 \mathrm{iP}$ for 'Blue River' (7.5), and $2.0 \mathrm{mg} \mathrm{dm}{ }^{-3} \mathrm{BAP}$ for 'Ellagance Purple' (6.9) and 'Munstead' (9.9). Chishti et al. (2006), too, had recorded that the MS medium supplemented with $2 \mathrm{mg} \mathrm{dm}^{-3} \mathrm{BAP}$ influenced the production of the greatest number of shoots. Those authors found that supplementation of the medium with BAP increased the number of shoots (15-45) to a greater extent than the addition of KIN (6-10). In the cultivar Munstead, BAP in a concentration of $0.8 \mathrm{mg} \mathrm{dm}^{-3}$ stimulated the number of shoots (16.5) to a greater extent than KIN (1-10.8) (Hamza et al. 2011). Also Leelavathi and Kuppan (2013) observed that the use of the same cytokinin $\left(2 \mathrm{mg} \mathrm{dm}^{-3} \mathrm{KIN}\right)$ influenced the 


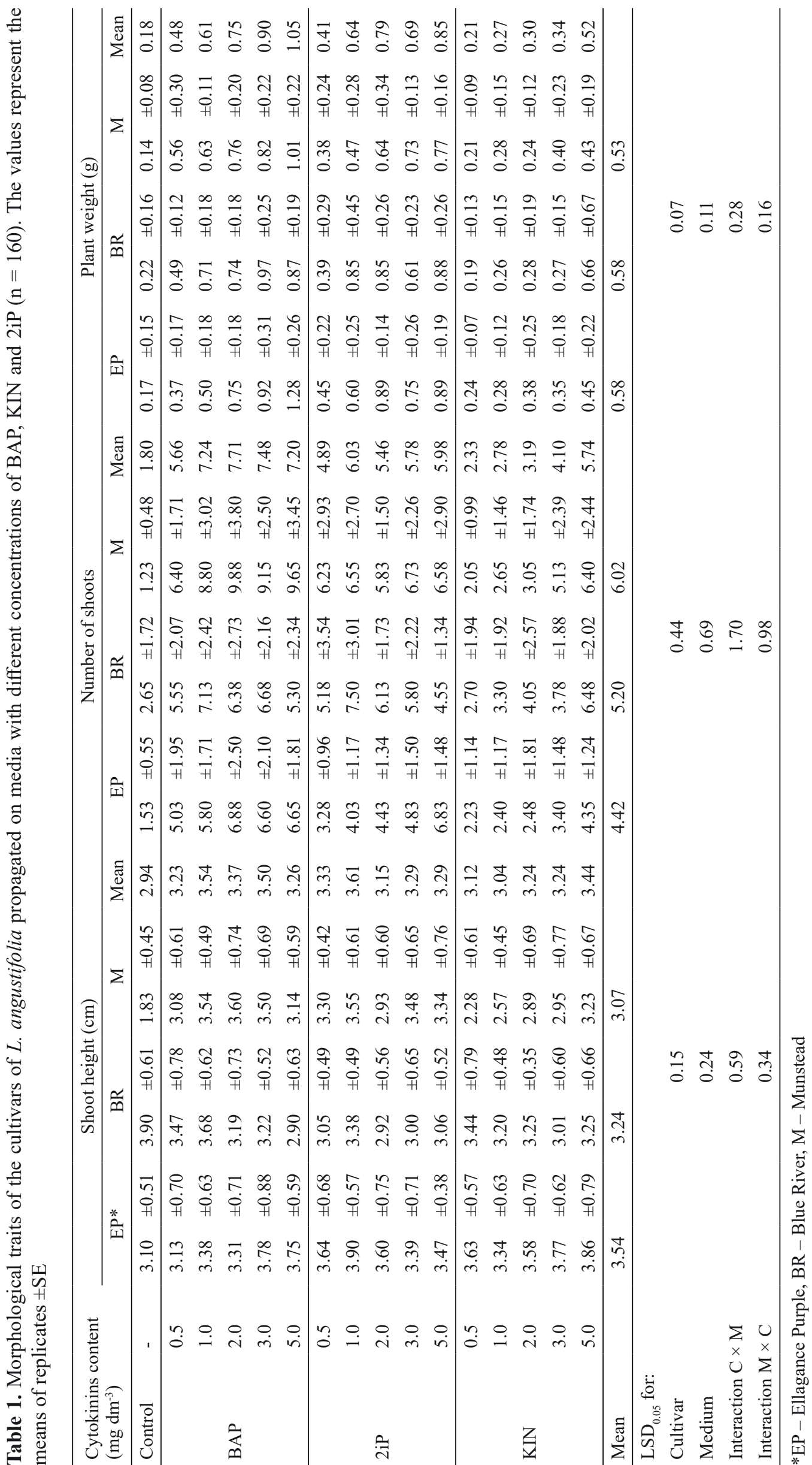


formation of a greater number (22.3) of shoots in L. angustifolia. Parkash and Singh (2013) demonstrated that a high concentration of auxin (15 mg dm${ }^{-3}$ IBA) had a significant influence on the elongation of leaves formed in L. angustifolia, yet kinetin ( $\left.2 \mathrm{mg} \mathrm{dm}^{-3} \mathrm{BAP}\right)$ increased their number. According to Kumar et al. (2015), the use of MS supplemented with cytokinin $\left(2 \mathrm{mg} \mathrm{dm}^{-3} \mathrm{BAP}\right)$ and auxin ( $0.5 \mathrm{mg} \mathrm{dm}^{-3}$ IAA) influences the increase in the number of shoots. Similar relationships were determined for L. angustifolia by Soni et al. (2013).

The majority of the media tested in this study had a positive influence on the plants, which were taller, weighed more, and were characterized by a greater number of shoots than the plants growing on the control medium.

\section{Rooting stage}

The use of IBA in a concentration of 0.1-0.2 and $0.75 \mathrm{mg} \mathrm{dm}^{-3}$ stimulated the formation of the root system, which was longest among all the examined cultivars (Tab. 2). The longest root system (1.1$2.5 \mathrm{~cm}$ ) was observed in all the cultivars in the presence of $0.2 \mathrm{mg} \mathrm{dm}^{-3}$ IBA. The auxin used at all the concentrations, except for $0.2 \mathrm{mg} \mathrm{dm}^{-3}$, had a positive influence on the height of the plants, which were considerably taller than the plants rooted in the control medium. The strongest influence on the height of cultivars was exerted by the media supplemented with $0.05 \mathrm{mg} \mathrm{dm}^{-3}$ IBA for 'Ellagance Purple' $(3.0 \mathrm{~cm}), 0.5 \mathrm{mg} \mathrm{dm}^{-3} \mathrm{IBA}$ for 'Blue River' $(3.7 \mathrm{~cm})$, and $0.07 \mathrm{mg} \mathrm{dm}{ }^{-3} \mathrm{IBA}$ for 'Munstead' (4.8 cm).
On the other hand, IBA in concentrations of $0.05-0.15,0.5-0.75$ and $1.5-1.75 \mathrm{mg} \mathrm{dm}^{-3}$ influenced the increase in the weight of the tested cultivars. The media stimulating the greatest weight gain were those supplemented with $0.15 \mathrm{mg} \mathrm{dm}^{-3}$ IBA for 'Ellagance Purple', $0.5 \mathrm{mg} \mathrm{dm}^{-3}$ IBA for 'Blue River', and $0.1,1.5-1.75 \mathrm{mg} \mathrm{dm}^{-3}$ IBA for 'Munstead'. The percentage of rooted plants was at a level of $85-95.6 \%$ compared with $4.4-7.5 \%$ for the control (Fig. 1).

Moreover, the conducted study determined the influence of media with different mineral compositions (MS, $1 / 2$ and $1 / 4$ MS) enriched with $0.2 \mathrm{mg} \mathrm{dm}^{-3}$ IBA or NAA on the height, root length and weight of the plants (Tab. 3). All of the media used had a positive influence on the formation of the root system in the examined cultivars. The roots were longer than in the plants growing on the control medium. The strongest influence on root length was exerted by $1 / 4 \mathrm{MS}$ supplemented with 0.2 $\mathrm{mg} \mathrm{dm}^{-3}$ NAA for 'Ellagance Purple' $(3.4 \mathrm{~cm}), 1 / 4$ MS supplemented with $0.2 \mathrm{mg} \mathrm{dm}^{-3}$ IBA for 'Blue River' $(2.2 \mathrm{~cm})$, and MS with the addition of $0.2 \mathrm{mg}$ $\mathrm{dm}^{-3}$ IBA for 'Munstead' $(1.9 \mathrm{~cm})$. The percentage of rooted plants was at a level of 87.5-96.3\% compared with $7.5-11.9 \%$ for the control (Fig. 2).

Hamza et al. (2011) had observed that the use of $1 / 2 \mathrm{MS}$ medium supplemented with $1 \mathrm{mg} \mathrm{dm}^{-3} \mathrm{NAA}$ resulted in a higher number of roots (21.25), yet the use of half the mineral composition of MS with the addition of $2 \mathrm{mg} \mathrm{dm}^{-3}$ IBA had the most positive influence on root length $(6 \mathrm{~cm})$. In their study, Chishti et al. (2006) had demonstrated that the best medium influencing the formation and length of the

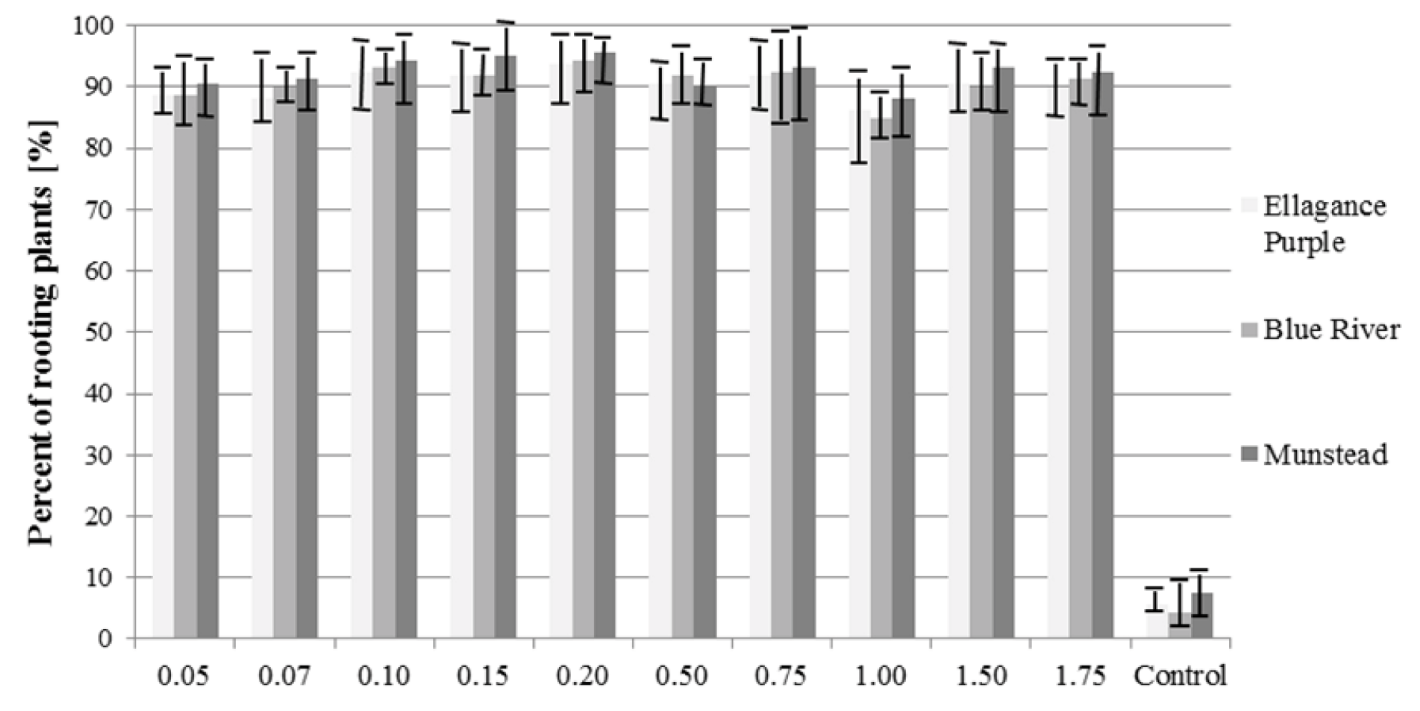

IBA content [mg dm-3

Figure 1. Influence of different concentrations of IBA $\left(\mathrm{mg} \mathrm{dm}^{-3}\right)$ on the percentage of rooted plants. Values are expressed as means $\pm \mathrm{SD}$ of three replicates 


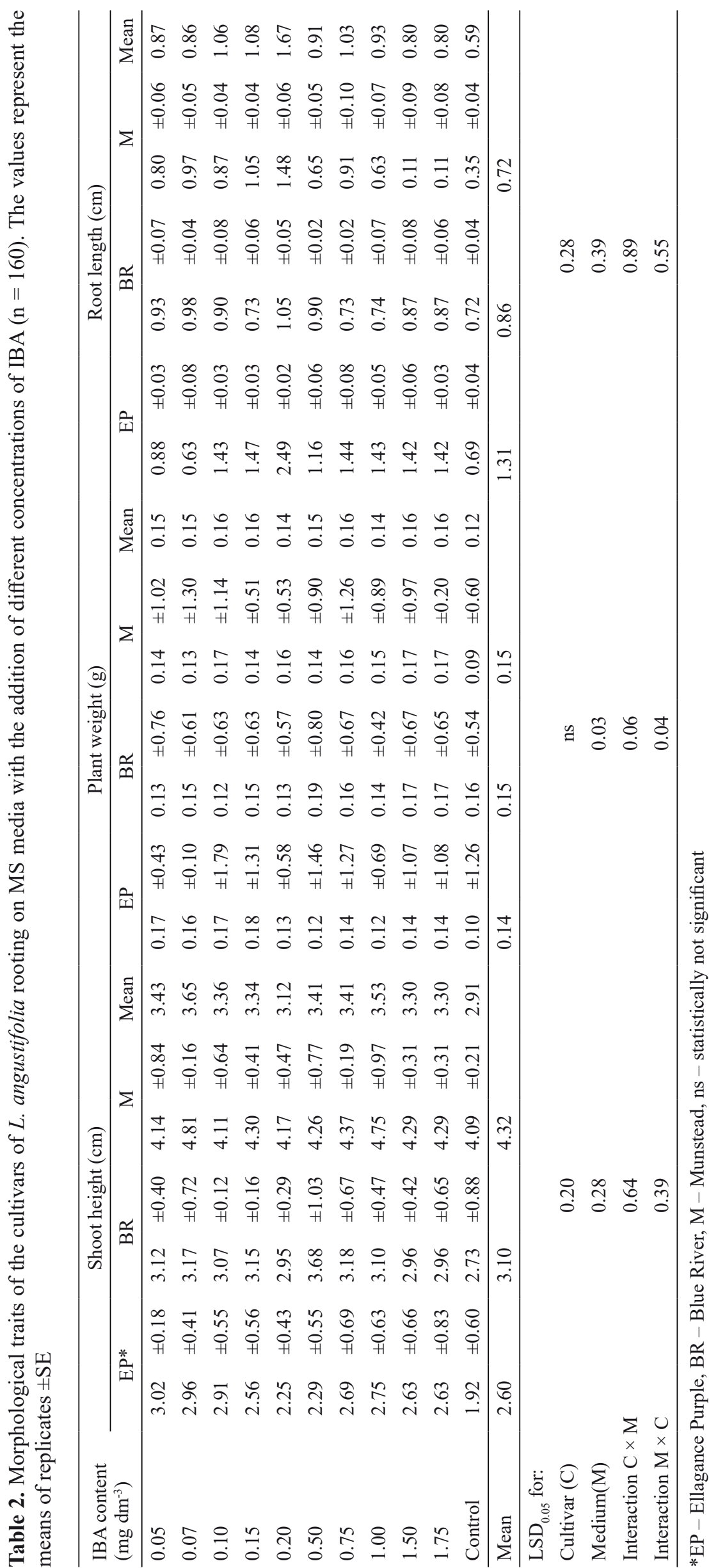




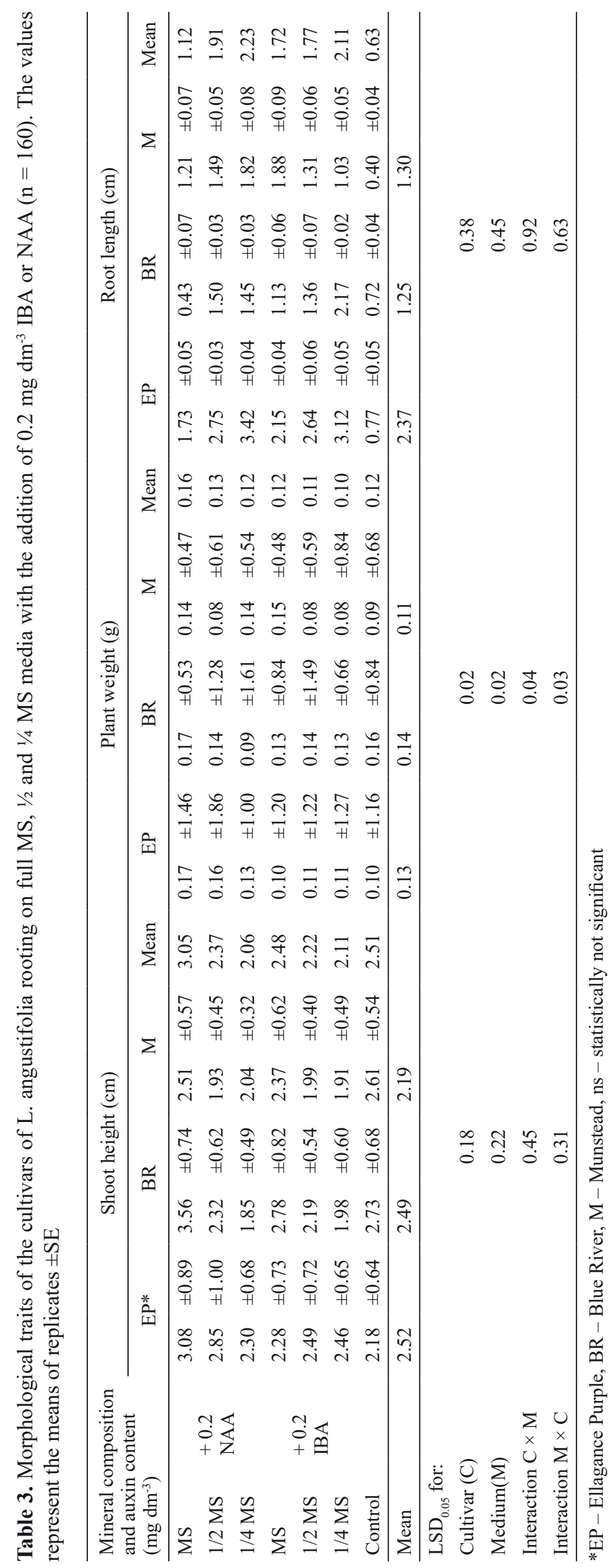




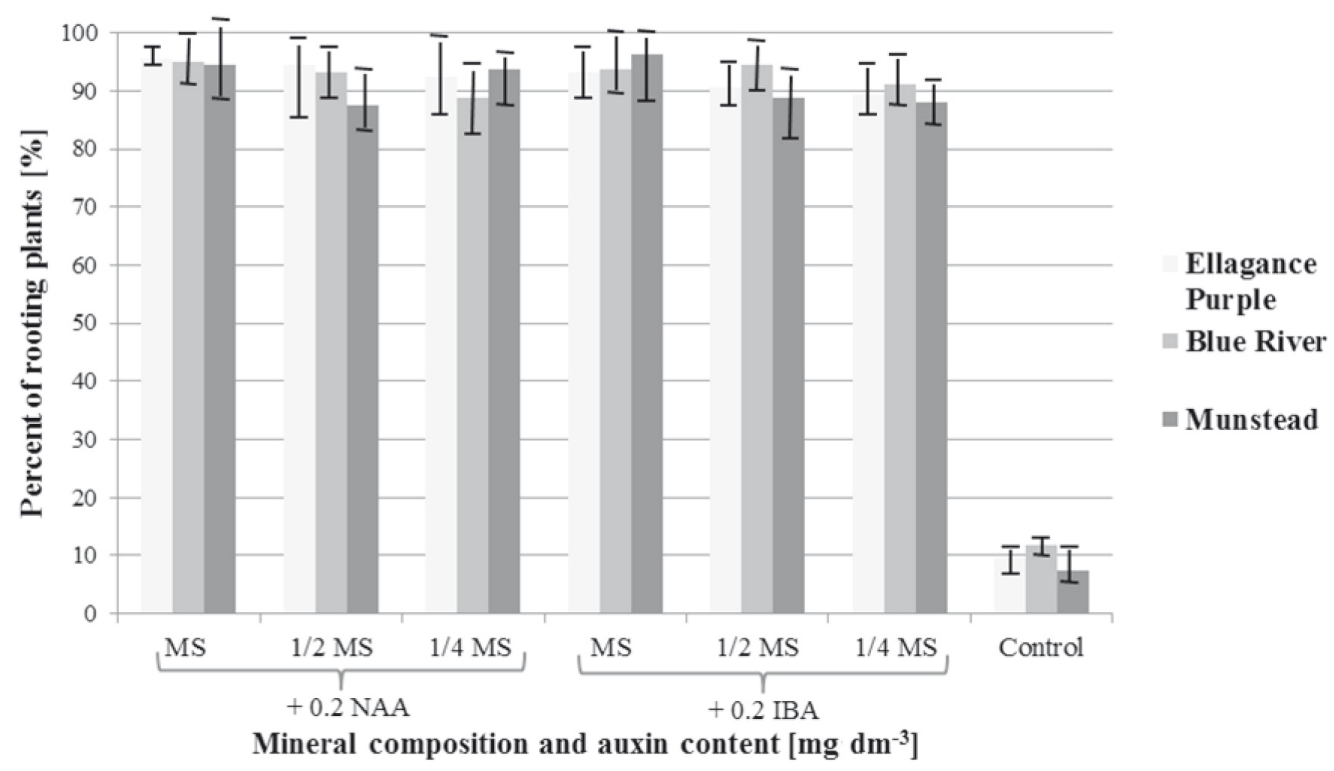

Figure 2. Influence of mineral composition and auxin content $\left(\mathrm{mg} \mathrm{dm}^{-3}\right)$ on the percentage of rooted plants. Values are expressed as means $\pm \mathrm{SD}$ of three replicates

root system was $1 / 2 \mathrm{MS}$ supplemented with $1 \mathrm{mg} \mathrm{dm}^{-3}$ IBA $(2.1 \mathrm{~cm})$, whereas in plants rooted on $1 / 2 \mathrm{MS}$ with $0.5 \mathrm{mg} \mathrm{dm}^{-3} \mathrm{IAA}$, the roots were considerably shorter $(1 \mathrm{~cm})$. For the rooting of microseedlings of L. angustifolia and L. latifolia, Al-Bakhit et al. (2007) used an MS medium supplied with NAA or IBA in concentrations of $0-0.5 \mathrm{mg} \mathrm{dm}^{-3}$. On each of the rooting media used, the formation of roots was noted, yet the media providing the best results were those containing $0.4 \mathrm{mg} \mathrm{dm}^{-3} \mathrm{NAA}$ or IBA. According to Jordan et al. (1998), L. dentata plants root perfectly on the MS medium with the macroelements content reduced by half and without the addition of growth regulators.

\section{Micromorphological analysis}

Researchers' opinions on the effect of plant propagation method on the morphology of secretory trichomes are divergent. Taha and Haron (2008) suggest that morphological and anatomical differences can be seen in the structure of leaves of plants cultivated under field and in vitro conditions, related to the conditions of their growth and development. Zuzarte et al. (2008, 2010) evaluated the structure and appearance of trichomes in L. pedunculata and observed that the trichomes, as well as the essential oils accumulated therein, from in vitro plants are identical to those from fieldgrown plants. In the present study, the diameter, as well as the number of trichomes per $1 \mathrm{~mm}^{2}$, were compared. Trichomes are found on both sides of the leaf and are attached to it by the stalk cell (Hallahan 2000, Turner and Croteau 2004).
Naidu and Shah (1981) were among the first researchers to conduct observations of trichomes in L. angustifolia. In their classification, which included other Lamiaceae genera, they divided trichomes into 5 groups, yet in L. angustifolia they observed 4 of them. Mesquita et al. (1992) noted that only two types of trichomes are found in L. stoechas. Yet, Zuzarte et al. (2010) divided the secretory glands in the Lavandula pedunculata into several types: peltate, capitate type I, capitate type II and bifurcated. Among the capitate trichomes, two types are distinguished: type I consists of a basal cell on a short, single-cell stalk with a round head, whereas type II consists of the basal cell, single-cell stalk, neck cell and a single-cell head. Both trichome types had been described earlier by Werker et al. (1985) for the Lamiaceae family. In the present study, fully developed peltate trichomes with a swollen head were observed (Fig. 3). Trichomes with a similar structure had been observed by Duarte and Souza (2014) in L. dentata. Secretory trichomes in all the tested cultivars had a greater diameter in the plants growing under natural conditions in comparison with the plants propagated in vitro (Fig. 4). The trichome size on the adaxial surface of leaf from field-grown plants was from $66.1 \mu \mathrm{m}$ to $73.1 \mu \mathrm{m}$, whereas on the abaxial side it was from $66.4 \mu \mathrm{m}$ to $73.8 \mu \mathrm{m}$ (Tab. 4). The differences were observed not only between the plants of different origins, but also between the tested cultivars of $L$. angustifolia. Smaller diameters of trichomes in plants from in vitro conditions occurred on the adaxial side of 


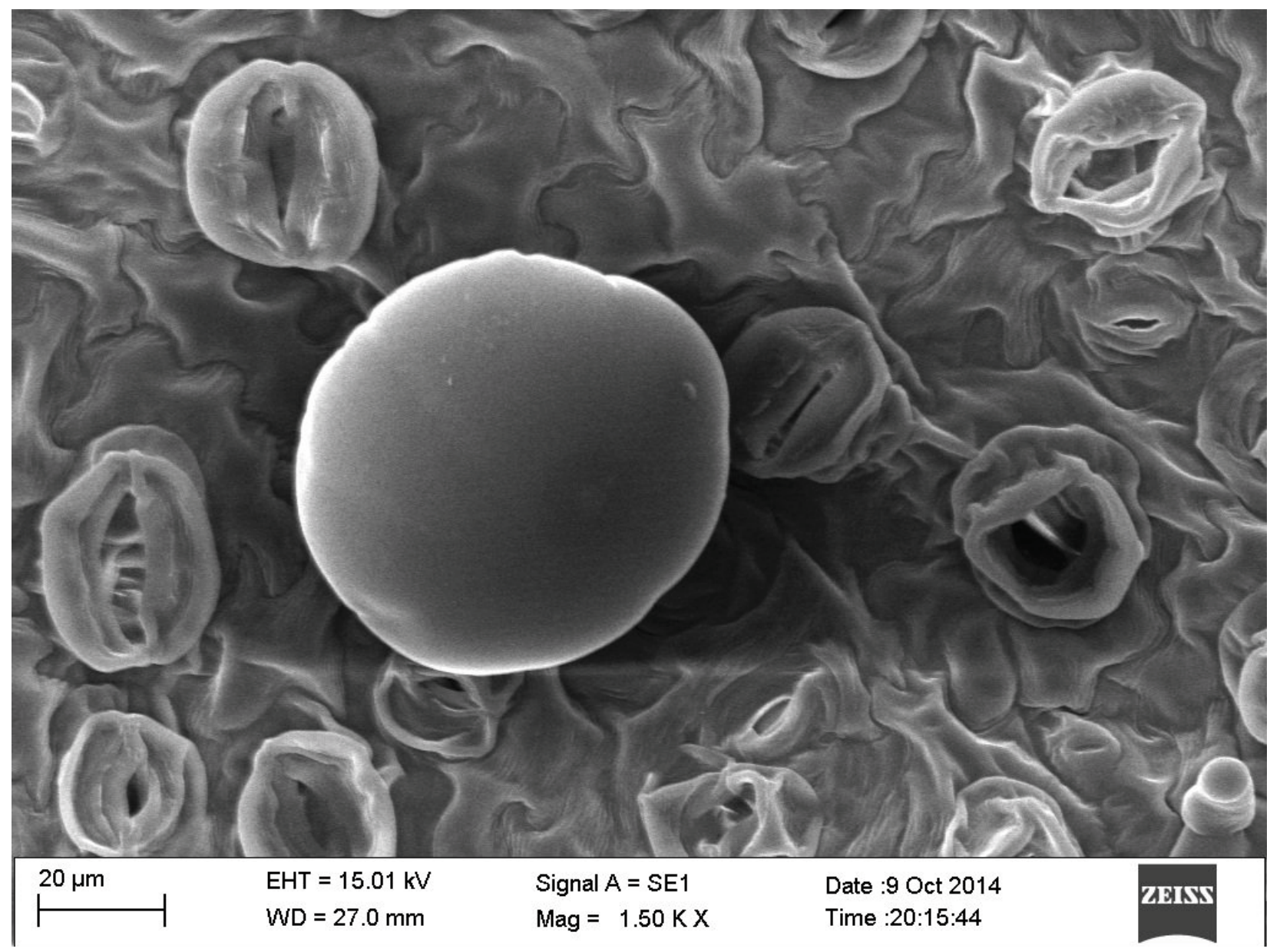

Figure 3. Fully developed peltate trichomes with a swollen head

the leaves of 'Munstead' and 'Ellagance Purple', and they were respectively $57.0 \mu \mathrm{m}$ and $67.1 \mu \mathrm{m}$, whereas those on the abaxial side were $54.6 \mu \mathrm{m}$ and $69.0 \mu \mathrm{m}$. However, trichomes in the cultivar Blue River from in vitro conditions were characterized by a particularly small diameter, adaxial $-28.0 \mu \mathrm{m}$, abaxial $-27.1 \mu \mathrm{m}$.
On the other hand, Machado et al. (2014) had noted that the number of trichomes in L. angustifolia was lower on both the abaxial and adaxial sides of the leaf of in vitro plants compared with the leaves of field-grown plants.

Thus far, no reports have been published on the number of trichomes per $1 \mathrm{~mm}^{2}$ of leaf surface for

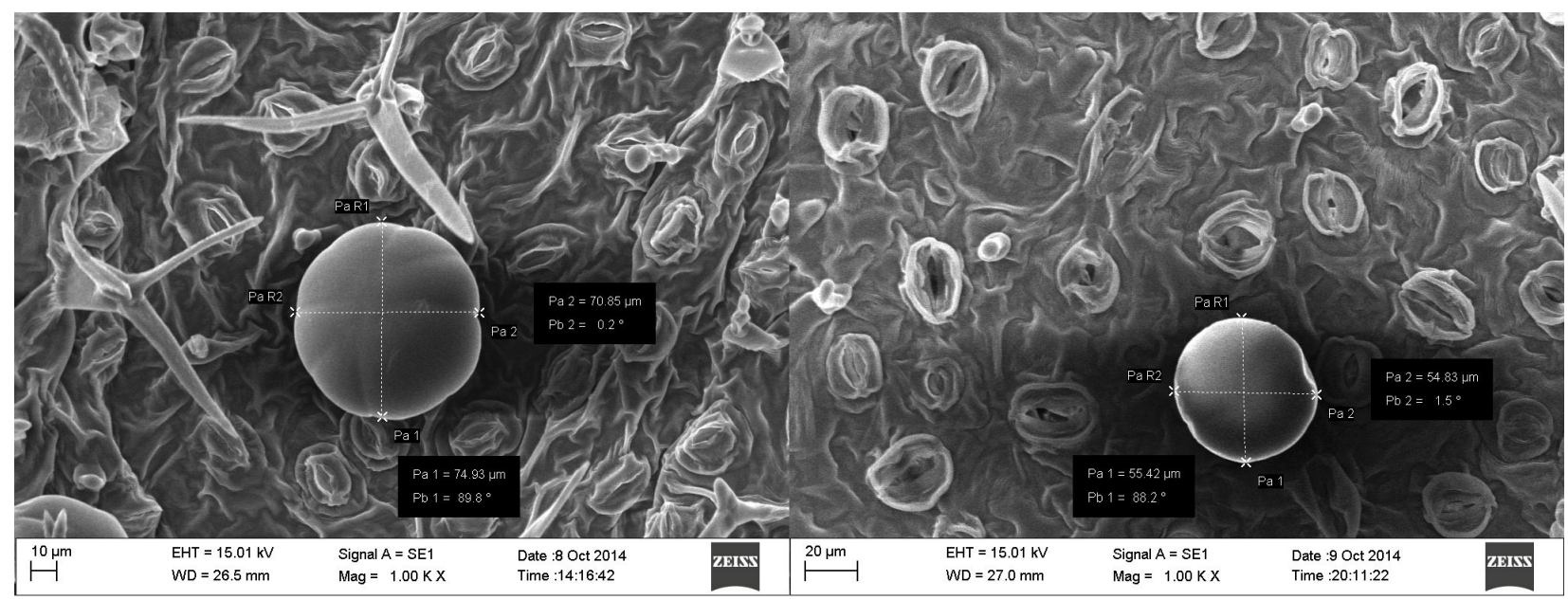

Figure 4. Trichomes of the cultivar Munstead on the abaxial surface of a leaf from field-grown (left) and in vitro propagated (right) plants 
Table 4. Size of secretory trichomes of L. angustifolia Mill. plants grown in field conditions and propagated in vitro $( \pm \mathrm{SE}, \mathrm{n}=3)$

\begin{tabular}{llcc}
\hline Cultivar $(\mathrm{C})$ & Growth conditions $(\mathrm{GC})$ & Adaxial surface of leaf $(\mu \mathrm{m})$ & Abaxial surface of leaf $(\mu \mathrm{m})$ \\
\hline \multirow{2}{*}{ Ellagance Purple } & field-grown* & $73.14 \pm 4.58$ & $73.80 \pm 5.93$ \\
& in vitro** & $67.14 \pm 8.34$ & $69.01 \pm 7.42$ \\
\cline { 2 - 4 } & Mean & 70.14 & 71.41 \\
\hline \multirow{2}{*}{ Blue River } & field-grown & $67.46 \pm 4.83$ & $66.36 \pm 5.93$ \\
& in vitro & $28.04 \pm 12.24$ & $27.08 \pm 14.22$ \\
\cline { 2 - 4 } & Mean & 47.75 & 46.72 \\
\hline \multirow{2}{*}{ Munstead } & field-grown & $66.14 \pm 3.18$ & $70.50 \pm 4.48$ \\
& in vitro & $57.04 \pm 10.40$ & $54.60 \pm 5.99$ \\
\cline { 2 - 4 } & Mean & 61.59 & 62.55 \\
\hline Mean * & 65.58 & 50.22 \\
Mean ** & 50.74 & 3.31 \\
\hline LSD ${ }_{0.05}$ for: & & & 2.80 \\
cultivar $(\mathrm{C})$ & 2.83 & 3.31 \\
growth conditions $(\mathrm{GC})$ & 1.96 & 3.54 \\
interaction $(\mathrm{C} \times \mathrm{GC})$ & 4.01 & \\
interaction $(\mathrm{GC} \times \mathrm{C})$ & 3.39 & \\
\hline
\end{tabular}

the cultivars of $L$. angustifolia tested in the present study. No statistically significant difference was observed in the number of secretory trichomes on the adaxial side of the leaves between the fieldgrown and in vitro plants. However, it was observed that the propagation of L. angustifolia in in vitro cultures had resulted in an increase in the number of secretory trichomes on the abaxial side of leaves (Tab. 5). The number of trichomes on the leaves of cultivars growing in natural conditions was 8.5 to 9 trichomes per $\mathrm{mm}^{2}$ on the adaxial side, and from 9.5 to 11 trichomes per $\mathrm{mm}^{2}$ on the abaxial side of the leaf. The plants propagated in vitro had from 8.5 to 10 trichomes per $\mathrm{mm}^{2}$ on the adaxial side, and

Table 5. Number of secretory trichomes of L. angustifolia Mill. plants grown in field conditions and propagated in vitro $( \pm \mathrm{SE}, \mathrm{n}=3)$

\begin{tabular}{|c|c|c|c|}
\hline Cultivar & Growth conditions (GC) & $\begin{array}{l}\text { Adaxial surface of leaf } \\
\text { Number of trichomes } \\
\text { per } \mathrm{mm}^{2}\end{array}$ & $\begin{array}{c}\text { Abaxial surface of leaf } \\
\text { Number of trichomes } \\
\text { per } \mathrm{mm}^{2}\end{array}$ \\
\hline \multirow{3}{*}{ Ellagance Purple } & field-grown* & $8.50 \pm 0.71$ & $9.50 \pm 0.71$ \\
\hline & in vitro** & $10.00 \pm 1.00$ & $11.00 \pm 1.41$ \\
\hline & Mean & 9.25 & 10.25 \\
\hline \multirow{3}{*}{ Blue River } & field-grown & $9.00 \pm 1.00$ & $10.00 \pm 1.00$ \\
\hline & in vitro & $9.50 \pm 0.50$ & $11.50 \pm 0.50$ \\
\hline & Mean & 9.25 & 10.75 \\
\hline \multirow{3}{*}{ Munstead } & field-grown & $8.75 \pm 0.96$ & $11.00 \pm 0.82$ \\
\hline & in vitro & $8.50 \pm 2.12$ & $12.50 \pm 2.89$ \\
\hline & Mean & 8.63 & 11.75 \\
\hline \multicolumn{2}{|l|}{ Mean * } & 8.75 & 10.17 \\
\hline \multicolumn{2}{|l|}{ Mean ** } & 9.33 & 11.67 \\
\hline \multicolumn{4}{|l|}{$\mathrm{LSD}_{0.05}$ for: } \\
\hline \multicolumn{2}{|c|}{ cultivar $(\mathrm{C})$} & $\mathrm{ns}$ & ns \\
\hline \multicolumn{2}{|c|}{ growth conditions (GC) } & ns & 1.24 \\
\hline \multicolumn{2}{|c|}{ interaction $(\mathrm{C} \times \mathrm{GC})$} & ns & ns \\
\hline \multicolumn{2}{|c|}{ interaction $(\mathrm{GC} \times \mathrm{C})$} & ns & ns \\
\hline
\end{tabular}

ns - statistically not significant 
from 11 to 12.5 trichomes per $\mathrm{mm}^{2}$ on the abaxial side of the leaf.

\section{Antimicrobial activity}

The antimicrobial activity of essential oils has been widely tested. Thus far, it has been determined that L. angustifolia oils inhibit the propagation of E. coli (Azar et al. 2011, Criste et al. 2014), Bacillus subtilis (Prabuseenivasan et al. 2006, Azar et al. 2011), S. aureus (De Martino et al. 2009, Criste et al. 2014), Enterococcus faecalis (Stanojević et al. 2011, Adaszyńska-Skwirzyńska et al. 2014), $P$. aeruginosa (Niculae et al. 2009, Criste et al. 2014), Listeria monocytogenes (Rota et al. 2004, Valizadeh et al. 2015), and of the fungi C. albicans (Rapper et al. 2013, Thosar et al. 2013), Aspergilloma and Aspergillosis (Uniyal et al. 2012).

Essential oils isolated from plants growing in in vitro cultures differ in their composition from the oils obtained from field-grown plants, thus the biological activity of these oils may differ (Gonçalves and Romano 2013). The present study determined antimicrobial properties of essential oils of the tested L. angustifolia cultivars, isolated from tissues of field-grown plants and in vitro plants. All the tested oils exhibited antimicrobial activity against $S$. aureus, $S$. epidermidis, E. coli, $P$. aeruginosa and $C$. albicans. It was observed that the essential oils originating from in vitro plants were characterized by considerably stronger antimicrobial activity than those isolated from field-grown plants (Tab. 6). The exceptions were the 'Blue River' oils against E. coli and 'Munstead' oils against $S$. aureus and $P$. aeruginosa, whose activities were at the same level, regardless of growth conditions.

In a study by Djenane et al. (2012), essential oils isolated from field-grown L. angustifolia had shown a higher antimicrobial activity against $S$. aureus (19.5 mm) than in our own study.

Ghardi et al. (2010) recorded sensitivity of an $S$. aureus strain to the effects of L. angustifolia essential oils, which was stronger than the sensitivity of $E$. coli and $P$. aeruginosa strains. Adaszyńska et al. (2013) tested field-grown essential oils of the same cultivars, yet the 'Ellagance Purple' oil did not show activity against $P$. aeruginosa, while the growth inhibition zone for oils isolated from 'Munstead' and 'Blue River' was $9.5 \mathrm{~mm}$ and $10 \mathrm{~mm}$ respectively, which was lower than in the present study. Different antimicrobial activity may be caused by the use of different $P$. aeruginosa strains. This had been demonstrated by the study by Imelouane et al. (2009), in which the essential oil of $L$. dentata from field-grown plants exhibited a different antimicrobial activity for different $S$. aureus strains (16-22 $\mathrm{mm})$.

In the study presented here, strong antimicrobial activity was observed in response to $S$. epidermidis on the part of the essential oils of in vitro 'Ellagance Purple' (17.8 mm), 'Blue River' (16.3 mm) and 'Munstead' (15.2 mm) plants as compared with the oils of field-grown plants $(11.2 \mathrm{~mm}, 10.2 \mathrm{~mm}$ and $12.4 \mathrm{~mm}$ respectively). Stronger antimicrobial activity was also shown by the oil from the 'Munstead' plants propagated in vitro against C. albicans $(17.8 \mathrm{~mm})$, as compared with the oil from field-grown plants $(12.3 \mathrm{~mm})$. Strong antimicrobial properties of essential oils were also recorded in response to the $E$. coli strain, where the antimicrobial activity for the oils isolated from in vitro plants of 'Ellagance Purple' and 'Munstead' was considerably higher (17.8 $\mathrm{mm}$ and $12.2 \mathrm{~mm})$ than for the oils from field-grown plants $(16.0 \mathrm{~mm}$ and $10.2 \mathrm{~mm}$ ).

Table 6. Antimicrobial activity of essential oil isolated from L. angustifolia Mill. plants grown in field conditions and propagated in vitro $( \pm \mathrm{SE}, \mathrm{n}=3)$

\begin{tabular}{llccccc}
\hline \multirow{2}{*}{ Essential oil } & \multicolumn{5}{c}{ Zone of bacterial/fungal growth inhibition (mm) } \\
\cline { 3 - 7 } & & \multicolumn{1}{c}{ S. aureus } & S. epidermidis & E. coli & P. aeruginosa & C. albicans \\
\hline \multirow{2}{*}{ Ellagance Purple } & field-grown & $10.62 \pm 0.35$ & $11.23 \pm 0.31$ & $16.01 \pm 0.78$ & $11.26 \pm 0.11$ & $13.01 \pm 0.34$ \\
& in vitro & $12.23 \pm 0.79$ & $17.82 \pm 0.41$ & $17.81 \pm 0.49$ & $12.24 \pm 0.39$ & $15.20 \pm 0.26$ \\
\multirow{3}{*}{ Blue River } & field-grown & $11.12 \pm 0.21$ & $10.23 \pm 0.37$ & $14.98 \pm 0.42$ & $13.21 \pm 0.51$ & $12.24 \pm 0.28$ \\
& in vitro & $14.23 \pm 0.68$ & $16.25 \pm 0.65$ & $16.28 \pm 0.28$ & $14.25 \pm 0.62$ & $14.25 \pm 0.17$ \\
\multirow{2}{*}{ Munstead } & field-grown & $9.35 \pm 0.66$ & $12.36 \pm 0.29$ & $10.24 \pm 0.61$ & $11.24 \pm 0.56$ & $12.32 \pm 0.19$ \\
\multirow{2}{*}{ Control - Antibiotic } & in vitro & $10.56 \pm 0.35$ & $15.23 \pm 0.48$ & $12.21 \pm 0.38$ & $10.98 \pm 0.44$ & $17.82 \pm 0.28$ \\
Control - DMSO & $23.68 \pm 0.28$ & $19.25 \pm 0.63$ & $21.18 \pm 0.58$ & $24.51 \pm 0.25$ & $21.05 \pm 0.27$ \\
\hline LSD & $6.00 \pm 0.37$ & $6.00 \pm 0.32$ & $6.00 \pm 0.26$ & $6.00 \pm 0.15$ & $6.00 \pm 0.37$ \\
\hline
\end{tabular}


Thus far, no reports have been published on the comparison of antimicrobial activity of essential oils isolated from $L$. angustifolia field-grown plants and plants propagated in vitro. Stronger antimicrobial activity of essential oils isolated from in vitro plants in comparison with the oils isolated from field-grown plants may be explained by the different chemical profile resulting from the different cultivation conditions (Andrys and Kulpa 2017).

\section{Determination of total polyphenol content}

Phenolic compounds are secondary metabolites common in plants. They contain hydroxyl groups bound directly to carbon atoms in the aromatic ring. They are divided into phenols, phenolic acids, phenylpropanoids, flavonoids, tannins, etc. Many of these compounds have antioxidant properties (Ghasemzadeh and Ghasemzadeh 2011, Kasote 2013). The amounts of polyphenols in herbaceous plants of the Lamiaceae family have been determined on several occasions (Proestos et al. 2006, Matkowski et al. 2008, Nikolova 2011, Belmekki and Bendimerad 2012). According to Duda et al. (2015), the amount of phenolic compounds in extracts from 3-year-old L. angustifolia plants was $12.44-18.16 \mathrm{mg} \mathrm{GAE} \mathrm{g}^{-1}$ DW. However, the amount of polyphenols in extracts from $L$. vera was $4.9 \mathrm{GAE} \mathrm{g}^{-1} \mathrm{DW}$ (Proestos et al. 2013). On the other hand, Robu et al. (2012) had demonstrated that the total polyphenol content of L. angustifolia 'Munstead' extracts was $80.70 \mathrm{mg}$ $\mathrm{g}^{-1}$ DW.

The present study has established that the amount of polyphenols in a lavender plant is influenced by its cultivation conditions. In field-grown plants, the level of these compounds was from $12.3 \mathrm{mg}$ GAE $\mathrm{g}^{-1} \mathrm{DW}$ to $21.7 \mathrm{mg} \mathrm{GAE} \mathrm{g}^{-1} \mathrm{DW}$, and in in vitro plants from $33.3 \mathrm{mg} \mathrm{GAE} \mathrm{g}^{-1} \mathrm{DW}$ to $37.0 \mathrm{mg}$ GAE $\mathrm{g}^{-1}$ DW. Research conducted by Makowczyńska et al. (2015) had shown that extracts of Ballota nigra propagated in vitro had a polyphenol content higher than extracts of field-grown plants.

\section{Determination of antioxidant activity}

Essential oils, extracts and dried plants of lavender have been studied for their antioxidant activity using the DPPH, FRAP and ABTS methods (Lee and Shibamoto 2002, Blažeković et al. 2010, Hui et al. 2010, Spiridon et al. 2011, Hamad et al. 2013, Proestos et al. 2013). Examinations of the capability to scavenge DPPH free radicals demonstrated that extracts from dried in vitro plants of all the tested cultivars were characterized by significantly higher antioxidant activity than extracts of dried fieldgrown plants (Tab. 7). The strongest antioxidant activity of the tested samples was shown by the extract from dried in vitro plants of 'Ellagance Purple' -37.4 mg TE g ${ }^{-1}$ DW, whereas the weakest activity was exhibited by the extract from dried

Table 7. Antioxidant activity of dried L. angustifolia Mill. plants grown in field conditions and propagated in vitro $( \pm \mathrm{SE}, \mathrm{n}=3)$

\begin{tabular}{|c|c|c|c|c|c|c|c|}
\hline \multirow{2}{*}{$\begin{array}{l}\text { Cultivar } \\
\text { (C) }\end{array}$} & \multirow{2}{*}{$\begin{array}{l}\text { Growth } \\
\text { conditions } \\
\text { (GC) }\end{array}$} & \multirow{2}{*}{$\begin{array}{l}\text { Polyphenols } \\
\text { (mg GAE g-1 } \\
\text { DW) }\end{array}$} & \multicolumn{2}{|c|}{ DPPH } & \multirow{2}{*}{$\begin{array}{c}\text { FRAP } \\
\text { mg } \mathrm{TE} \mathrm{g}^{-1} \mathrm{DW}\end{array}$} & \multicolumn{2}{|c|}{ ABTS } \\
\hline & & & $\mathrm{mg} \mathrm{TE} \mathrm{g-1} \mathrm{DW}$ & $\%$ inhibition & & $\mathrm{mg} \mathrm{TE} \mathrm{g}^{-1} \mathrm{DW}$ & TAA $\%$ \\
\hline \multirow{3}{*}{$\begin{array}{l}\text { Ellagance } \\
\text { Purple }\end{array}$} & field-grown* & $16.77 \pm 1.57$ & $16.18 \pm 1.24$ & $35.55 \pm 1.82$ & $19.69 \pm 0.94$ & $38.01 \pm 1.84$ & $47.87 \pm 2.14$ \\
\hline & in vitro** & $35.24 \pm 1.03$ & $37.42 \pm 0.17$ & $86.10 \pm 0.45$ & $58.13 \pm 2.05$ & $82.52 \pm 0.08$ & $99.62 \pm 0.10$ \\
\hline & Mean & 29.31 & 30.39 & 72.16 & 47.39 & 64.82 & 79.04 \\
\hline \multirow{3}{*}{ Blue River } & field-grown & $21.66 \pm 1.84$ & $23.58 \pm 1.17$ & $56.11 \pm 1.19$ & $30.93 \pm 1.51$ & $47.49 \pm 1.85$ & $58.89 \pm 2.15$ \\
\hline & in vitro & $36.95 \pm 0.88$ & $37.20 \pm 0.35$ & $88.21 \pm 0.29$ & $63.84 \pm 4.81$ & $82.15 \pm 0.85$ & $99.19 \pm 0.98$ \\
\hline & Mean & 26.01 & 26.80 & 60.83 & 38.91 & 60.27 & 73.75 \\
\hline \multirow{3}{*}{ Munstead } & field-grown & $12.33 \pm 0.55$ & $8.26 \pm 0.07$ & $21.23 \pm 2.89$ & $9.21 \pm 0.64$ & $28.02 \pm 1.53$ & $36.25 \pm 1.79$ \\
\hline & in vitro & $33.30 \pm 2.38$ & $35.07 \pm 2.65$ & $83.31 \pm 1.81$ & $42.77 \pm 0.90$ & $78.53 \pm 3.35$ & $94.98 \pm 3.89$ \\
\hline & Mean & 22.82 & 21.66 & 52.27 & 25.99 & 53.28 & 65.62 \\
\hline Mean * & & 16.92 & 16.01 & 37.63 & 19.94 & 37.84 & 47.67 \\
\hline Mean ** & & 35.16 & 36.56 & 85.87 & 54.91 & 81.07 & 97.93 \\
\hline \multicolumn{8}{|l|}{$\mathrm{LSD}_{0.05}$ for: } \\
\hline cultivar & & 1.90 & 1.29 & 2.32 & 2.89 & 2.36 & 2.74 \\
\hline growth conc & itions & 1.55 & 1.05 & 1.89 & 2.36 & 1.93 & 2.24 \\
\hline interaction & $\mathrm{C} \times \mathrm{GC})$ & 3.28 & 2.23 & 4.01 & 5.01 & 4.08 & 4.75 \\
\hline interaction & $\mathrm{GC} \times \mathrm{C})$ & 1.23 & 1.03 & 2.01 & 4.23 & 1.56 & 1.21 \\
\hline
\end{tabular}


in vitro 'Munstead' plants - $35.1 \mathrm{mg} \mathrm{TE} \mathrm{g}^{-1} \mathrm{DW}$, while for the 'Blue River' plants it was $37.2 \mathrm{mg}$ TE $\mathrm{g}^{-1} \mathrm{DW}$. The antioxidant potential of extracts from dried field-grown plants was different, and considerably lower, amounting to $8.3 \mathrm{mg} \mathrm{TE} \mathrm{g}^{-1} \mathrm{DW}$ for 'Munstead', $16.2 \mathrm{mg} \mathrm{TE} \mathrm{g}^{-1} \mathrm{DW}$ for 'Ellagance Purple', and 23.6 mg TE g ${ }^{-1}$ DW for 'Blue River'. Dried stems and leaves of lavender were used in the present study, and according to Blažeković et al. (2010), the antioxidant activity is higher in the stems than in the leaves. Robu et al. (2012) had tested extracts of L. angustifolia 'Munstead' and noted that the free radical scavenging activity, measured using the DPPH method for the concentration of 2.5 $\mathrm{mg} \mathrm{ml}^{-1}$, was $21.41 \%$. In vitro plants exhibit stronger antioxidant activity than field-grown plants. Kousalya and Bai (2016), among others, observed higher antioxidant activity using the DPPH method for extracts of Canscora decussata propagated in vitro. Sheena and Jothi (2015) observed this relationship while analyzing extracts of in vitro plants of Orthosiphon stamineus, the antioxidant activity of which was 52.1-81.1 $\mu \mathrm{g} \mathrm{ml}^{-1}$, and higher than for extracts from wild plants - 27.51-80.57 $\mu \mathrm{g} \mathrm{ml} l^{-1}$. The differences are in accordance with an earlier study on methanolic extracts of Salvia officinalis plants propagated in in vitro cultures, which exhibited considerably higher antioxidant activity $\left(70.1 \mu \mathrm{g} \mathrm{ml}^{-1}\right)$ determined using the DPPH method as compared with extracts from plants cultivated under natural conditions $\left(23.2 \mu \mathrm{g} \mathrm{ml}^{-1}\right)$ (Grzegorczyk et al. 2007).

In the study presented here, a considerably higher antioxidant potential, determined using the FRAP method, was observed for the dried in vitro plants. It was, respectively: $42.8 \mathrm{mg} \mathrm{TE}^{-1} \mathrm{DW}$ for 'Munstead', $58.1 \mathrm{mg} \mathrm{TE} \mathrm{g}^{-1} \mathrm{DW}$ for 'Ellagance Purple', and $63.8 \mathrm{mg} \mathrm{TE} \mathrm{g}^{-1} \mathrm{DW}$ for 'Blue River', whereas it was at least two times lower for the fieldgrown plants: $9.2 \mathrm{mg} \mathrm{TE} \mathrm{g}^{-1} \mathrm{DW}$ for 'Munstead', $19.7 \mathrm{mg} \mathrm{TE} \mathrm{g}^{-1}$ DW for 'Ellagance Purple', and $30.9 \mathrm{mg} \mathrm{TE} \mathrm{g}^{-1}$ DW for 'Blue River'. It should be emphasized that the antioxidant activity tested using the ABTS method was characterized by higher values for the dried in vitro plants than for the field-grown plants, and it was highest for the dried plant material of 'Ellagance Purple' - $82.5 \mathrm{mg}$ $\mathrm{TE} \mathrm{g}^{-1} \mathrm{DW}$, whereas for the remaining cultivars it was $82.2 \mathrm{mg} \mathrm{TE} \mathrm{g}^{-1} \mathrm{DW}$ for 'Blue River' and 78.5 mg TE $\mathrm{g}^{-1}$ DW for 'Munstead'. Dried field-grown plants of 'Munstead' exhibited almost 3 times lower activity (28.0 $\left.\mathrm{mg} \mathrm{TE} \mathrm{g}^{-1} \mathrm{DW}\right)$ than the dried in vitro plants. Lower values were also exhibited by dried plants of the remaining cultivars $(38.0 \mathrm{mg}$ TE $\mathrm{g}^{-1} \mathrm{DW}$ - 'Ellagance Purple', $47.5 \mathrm{mg}$ TE $\mathrm{g}^{-1} \mathrm{DW}$ - 'Blue River').

The activity of antioxidant enzymes in cells increases as a response to environmental stresses (Mohammadi et al. 2011). In vitro plant propagation stresses the plant, and the presence of macro- and microelements in the medium and their transport within the plant do not only influence its growth, but also cause an increase in the concentration of biologically active substances which play the role of antioxidants (Khenifi et al. 2011). Andrys and Kulpa (2017) demonstrated that in vitro propagation of plants results in a changed chemical composition of essential oils and promotes the synthesis of antioxidant compounds such as carvacrol and thymol, which may affect the antioxidant activity of extracts from in vitro and field-grown plants (Baser et al. 1991). Higher values of the antioxidant potential of extracts obtained from in vitro plants may also stem from the fact that the damaging of plant tissue for the purpose of conducting tissue cultures and its introduction into the medium results in an increase in the level of jasmonic acid (JA) in the plant, resulting in the expression of protective genes, thus causing an accumulation of secondary metabolites (Creelman and Mullet 1997, Kant et al. 2004). JA is synthesized from $\alpha$-linoleic acid (Browse and Somerville 1991), and an increase in its concentration has been observed in damaged plant tissues (Conconi et al. 1996, Ryu and Wang 1998). The release of $\alpha$-linolenic acid from membranes of plant cells is considered an important step in the control of JA synthesis and production of secondary metabolites. Stehfest et al. (2004), who added JA to suspension cultures of Lavandula officinalis, had obtained large amounts of rosmarinic acid (RA), and Nitzsche et al. (2004), apart from RA, had also obtained high levels of caffeic acid.

\section{CONCLUSIONS}

The study demonstrated that micropropagation of lavender plants on media with BAP and 2iP at a concentration of $0.5-5 \mathrm{mg} \mathrm{dm}^{-3}$ and KIN at $2-5 \mathrm{mg} \mathrm{dm}^{-3}$ affected the increase in the height and weight of the plants, while the same concentration of BAP and $2 \mathrm{iP}$ and $1-5 \mathrm{mg} \mathrm{dm}^{-3} \mathrm{KIN}$ had a positive influence on the number of shoots. On the other hand, media with full mineral content and reduced down to $1 / 2$ and $1 / 4$ MS and supplemented with $0.2 \mathrm{mg} \mathrm{dm}^{-3}$ IBA or NAA influenced, in most cases, the elongation of roots in comparison with the control medium. The results of the study 
also demonstrate that in vitro plant cultures may constitute an important tool contributing to the increase in the synthesis of biologically active compounds in the plant which cause elevated antioxidant and antimicrobial activities of dried plants and essential oils in comparison with fieldgrown plants. The above results demonstrate that in vitro conditions influence the properties of essential oils and extracts. The analyzed dried plant material from in vitro cultures contained large amounts of polyphenolic compounds and showed strong antioxidant activity as determined by the DPPH, FRAP and ABTS methods. Increased antimicrobial activity of essential oils was observed for the oils isolated from lavender micropropagated in vitro in comparison with field-grown plants. Micropropagation of lavender plants also caused a decrease in the diameter of secretory trichomes, compared with field-grown plants. According to the research conducted by Andrys and Kulpa (2017), the composition of essential oils isolated from tissue of in vitro propagated lavender differs from that of oils isolated from field-grown plants, which could have an effect on the increased antioxidant and antimicrobial activities of micropropagated plants in comparison with field-grown lavender. Increased antioxidant and antimicrobial activities of essential oils and extracts make them suitable for direct industrial use, especially by the cosmetics industry.

\section{AUTHOR CONTRIBUTIONS}

D.A. and D.K. - developed the concept and designed the experiment; D.A., M.G., M.B., A.D. - collected data and performed analyses; D.A. and D.K. - analysed the data and wrote the paper.

\section{CONFLICT OF INTEREST}

Authors declare no conflict of interest.

\section{REFERENCES}

Adaszyńska M., Swarcewicz M., Dzięciol M., DobrowolsKa A., 2013. Comparison of chemical composition and antibacterial activity of lavender varieties from Poland. Nat. Prod. Res. 27(16): $1497-$ 1501.

AdASZyŃSKA-SkwirzyŃSKa M., Swarcewicz M., DobrowolsKa A., 2014. The potential of use lavender from vegetable waste as effective antibacterial and sedative agents. Med. Chem. 4(11): 734-737.

Adsersen A., Gauguin B., Gudiksen L., Jager, A.K., 2006. Screening of plants used in Danish folk medicine to treat memory dysfunction for acetylcholinesterase inhibitory activity. J. Ethnopharmacol. 104: 418-422.

Akbar J.A., Shohrati M., Mahmoudi R., Haj H.R., Nosratpour S., Pajohi-Alamoti M., Mohamad L.A., 2014. Chemical composition and biological activities of Scrophularia striata extracts. Minerva Biotecnologica 26(3): 183-189.

Al-Bakhit A.A.M., Sawwan J.S., Al-Mahmoud M.S., 2007. In vitro propagation of two Lavandula species: Lavandula angustifolia and Lavandula latifolia L. Medica. J. J. Agr. Sci. 3(1): 16-25.

Andrys D., KulPA D., 2017. In vitro propagation affects the composition of narrow-leaved lavender essential oils. Acta Chromatogr. (in press). DOI: 10.1556/1326.2017.00317.

Azar P.A., Torabbeigi M., Sharifan A., Tehrani M.S., 2011. Chemical composition and antibacterial activity of the essential oil of Lavandula angustifolia isolated by solvent free microwave assisted extraction and hydrodistillation. J. Food Biosci, Tech., Islamic Azad University, Science and Research Branch. 1: 19-24.

Basch E., Foppa I., Liebowitz R., Nelson J., Smith M., Sollars D., Ulbricht C., 2004. Lavender (Lavandula angustifolia Miller). J. Herbal Pharmacother. 4(2): 63-78.

Baser K.H.C., Sezik E., Tumen G., 1991. Composition of the essential oil of Ziziphora clinopodioides Lam. J. Essential oil Res. 3: 237-239.

BelmekKi N., Bendimerad N., 2012. Antioxidant activity and phenolic content in methanol crude extracts from three Lamiaceae grown in southwestern Algeria. J. Nat. Prod. Plant Resour. 2 (1): 175-181.

Blažeković B., Vladimir-Knežević S., Brantner A., BIVAL Š.M., 2010. Evaluation of antioxidant potential of Lavandula $\times$ intermedia Emeric ex Loisel. 'Budrovka: a comparative study with L. angustifolia Mill. Molecules 15: 5971-5987.

Browse J., Somerville C., 1991. Glycerolipid synthesis: Biochemistry and regulation. Annu. Rev. Plant Physiol. Plant Mol. Biol. 42: 467-506.

Cavanagh H.M.A., Wilkinson J.M., 2002. Biological activities of lavender essential oil. Phytother. Res. 16: 301-308.

Chew K.K., Khoo M.Z., NG S.Y., Thoo Y.Y., WAn Aida W.M., Ho C.W., 2011. Effect of ethanol concentration, extraction time and extraction temperature on the recovery of phenolic compounds and antioxidant capacity of Orthosiphon stamineus extracts. Int. Food Res. J. 18(4): 1427-1435.

Chishti N., Kaloo Z.A., Shawl A.S., Sultan P., 2006. Rapid in vitro clonal propagation of Lavendula officinalis chaix a multipurpose plant of industrial importance. Pakistan Journal of Biological Sciences. 9(3): 514-518.

Conconi A., Miquel M., Browse J., Ryan C.A., 1996. Intracellular levels of free linolenic andlinoleic acids 
increase in tomato leaves in response to wounding. Plant Physiol. 111: 797-803.

Cong Y., Abulizi P., Zhi L., Wang X., Mirensha, 2008. Chemical composition of the essential oil from Lavandula angustifolia from Xinjiang. China. Chem. Nat. Comp. 44(6): 810.

Creelman R.A., Mullet J.E., 1997. Biosynthesis and action of jasmonates in plants. Annu. Rev. Plant Physiol. Plant Mol. Biol. 48: 355-381.

Criste A., Giuburuncă M., Negrea O., Fit N., 2014. Research concerning antimicrobial activities of some essential oils extracted from plants. J. Anim. Sci. Biotechnol. 47(2): 67-72.

Darbre P.D., Aluarrah A., Miller W.R., Coldham N.G., Sauer M.J., PoPe, M.G., 2004. Concentrations of parabens in human breast tumours. J. Appl. Toxicol. 24: 5-13.

De Martino L., De Feo V., Nazzaro F., 2009. Chemical composition and in vitro antimicrobial and mutagenic activities of seven Lamiaceae essential oils. Molecules 14(10): 4213-4230.

Demissie Z.A., SARKer L.S., Mahmoud S.S., 2011. Cloning and functional characterization of $\beta$-phellandrene synthase from Lavandula angustifolia. Planta. 233: 685-696.

Djenane D., AïDer M., YAngüEla J., IDIR L., Gómez D., RonCALÉs P., 2012. Antioxidant and antibacterial effects of Lavandula and Mentha essential oils in minced beef inoculated with E. coli $\mathrm{O} 157: \mathrm{H} 7$ and $S$. aureus during storage at abuse refrigeration temperature. Meat Sci. 92(4): 667-674.

DuArte M.R., Souza D.C., 2014. Microscopic characters of the leaf and stem of Lavandula dentata L. (Lamiaceae). Microsc. Res. Tech. 77(8): 647-652.

Duda S.C, Mărghitaş L.A., Dezmirean D., Duda M., MărgăoAna R., Bobiş O., 2015. Changes in major bioactive compounds with antioxidant activity of Agastache foeniculum, Lavandula angustifolia, Melissa officinalis and Nepeta cataria: Effect of harvest time and plant species. Ind. Crops Prod. 77: 499-507.

European Pharmacopoeia, 2004. 4th ed. Version 4.08., Strasbourg: EDQM. 3158-9.

Falk L., Biswas K., Boeckelmann A., Lane A., Mahmoud S.S., 2009. An efficient method for the micropropagation of lavenders: Regeneration of a unique mutant. J. Essent. Oil Res. 21(3): 225-228.

Ghardi T.A., Mousavi S.L., Sharafi S.M., Astaneh S.D.A., RezaeE M.B., 2010. Antimicrobial, antioxidant, hematologic and cytotoxic properties of Lavandula angustifolia essential oil. Modares J. Med. Sci. 12(4): 54-58.

Ghasemzadeh A., Ghasemzadeh N., 2011. Flavonoids and phenolic acids: Role and biochemical activity in plants and human. J. Med. Plants Res. 5(31): $6697-$ 6703.

Ghelardini C., Galeotti N., Salvatore G., Mazzanti G., 1999. Local anaesthetic activity of the essential oil of Lavandula angustifolia. Planta Med. 65(8): 700-703.

Gonçalves S., Romano A., 2013. In vitro culture of lavenders (Lavandula spp.) and the production of secondary metabolites. Biotechnol. Adv. 31(2): 166174.

Grzegorczyk I., MatKowski A., Wysokińska H., 2007. Antioxidant activity of extracts from in vitro cultures of Salvia officinalis L. Food Chemistry. 104: 536-541.

Hallahan D.L., 2000. Monoterpenoid biosynthesis in glandular trichomes of Labiate plants. In: D.L. Hallahan and J.C. Gray (eds), Advances in Botanical Research, Academic Press, San Diego 31: 77-120.

Hamad K.J., Al-Shaheen S.J.A., Kaskoos R.A., Ahamad J., JameEl M., Mir S.R., 2013. Essential oil composition and antioxidant activity of Lavandula angustifolia from Iraq. Int. Res. J. Pharm. 4(4): 117120.

Hamza A.M., Omaima M.A.E.K., Kasem M.M., 2011. Direct micropropagation of English lavender (Lavandula angustifolia Munstead) plant. J. Plant Production, Mansoura Univ. 2(1): 81-96.

Hui L., He L., Huxan L., Xiaolan L., AiGuo Z., 2010. Chemical composition of lavender essential oil and its antioxidant activity and inhibition against rhinitis-related bacteria. Afr. J. Microbiol. Res. 4(4): 309-313.

Imelouane B., Elbachiri A., Ankit M., Benzeid H., Khedid K., 2009. Physico-chemical compositions and antimicrobial activity of essential oil of Eastern Moroccan Lavandula dentata. Int. J. Agric. Biol. 11(2): 113-118.

Jordan A.M., Calvo M.C., Segura J., 1998. Micropropagation of adult Lavandula dentata plants. J. Hort. Sci. Biotechnol. 73: 93-96.

Kara N., BAYDAR H., 2013. Determination of lavender and lavandin cultivars (Lavandula sp.) containing high quality essential oil in Isparta., Turkey. Turk. J. Field Crops. 18(1): 58-65.

Kant M.R., Ament K., Sabelis M.W., Haring M.A., SchUURINK R.C., 2004. Differential timing of spider mite-induced direct and indirect defenses in tomato plants. Plant Physiol. 135: 483-495.

Kasote D.M., 2013. Flaxseed phenolics as natural antioxidants. Inter. Food Res. J. 20(1): 27-34.

Khenifi M.L., Boudjeniba M., Kameli A., 2011. Effects of salt stress on micropropagation of potato (Solanum tuberosum L.). Afr. J. Biotech. 10(40): 7840-7845.

Kousalya L., Bai N., 2016. Effect of growth regulators on rapid micropropagation and antioxidant activity of Canscora decussata (Roxb.) Roem. \& Schult. - A threatened medicinal plant. Asian Paci. J. Reprod. 5(2): 161-170.

Kumar A., Kaushal S., Sharma S., 2015. Studies on influence of growth regulators in micropropagation of Lavandula angustifolia. IJABPT 6(2): 73-77. 
Kumaran A., KarunaKaran R.J., 2007. In vitro antioxidant activities of methanol extracts of five Phyllanthus species from India. LWT 40: 344-352.

Landmann C., Fink B., Festner M., Dregus M., Engel K.H., Schwab W., 2007. Cloning and functional characterization of three terpene synthases from lavender (Lavandula angustifolia). Arch. Biochem. Biophys. 465: 417-429.

LeE K.G., Shibamoto T., 2002. Determination of antioxidant potential of volatile extracts isolated from various herbs and spices. J. Agric. Food Chem. 50(17): 4947-4952.

Leelavathi D., Kuppan N., 2013. Protocol for rapid clonal multiplication using in vitro apical bud of Lavandula angustifolia. J. Pharm. Biol. Sci. 7(3): 9698.

Lis-BAlchin M., HART S., 1997. A preliminary study of the effect of essential oils on skeletal and smooth muscle in vitro. J. Ethnopharmacol. 58: 183-187.

Lis-Balchin M., Hart S., 1999. Studies on the mode of action of the essential oil of Lavender (Lavandula angustifolia P. Miller). Phytother. Res. 13(4): 540542.

Machado M.P., Silva A.L.L., Biasi L.A., Deschamps C., Filho J.C.B., Zanette F., 2014. Influence of calcium content of tissue on hyperhydricity and shoot-tip necrosis of in vitro regenerated shoots of Lavandula angustifolia Mill. Braz. Arch. Biol. Technol. 57(5): 636-643.

Mahmoudi R., Nosratpour S., 2013. Teucrium polium L. essential oil: Phytochemiacl component and antioxidant properties. Int. Food Res. J. 20(4): $1697-$ 1701.

MAKOWCZYŃSKA J., GRZEGORCZYK-KAROLAK I., WYSOKIŃSKA H., 2015. Antioxidant activity of tissue culture-raised Ballota nigra L. plants grown ex vitro. Acta Pol. Pharm. 72(4): 769-775.

Matkowski A., Tasarz P., Szypula E., 2008. Antioxidant activity of herb extracts from five medicinal plants from Lamiaceae, subfamily Lamioideae. J. Med. Plants Res. 2(11): 321-330.

Mesquita J.F., Proença da Cunha A., Santos Dias J.D., Guimarães M.L., 1992. The leaf indument of both spontaneous and in vitro regenerated plants of Lavandula stoechas L.: SEM study and analysis of the secretion. In: Electron Microscopy, Eurem 92, Vol. 3. L. Megias-Megias (ed), Secretariado de Publicaciones de la Universidad de Granada, Spain.

Mohammadi A., Habibi D., Rohami, M., Mafakheri S., 2011. Effect of drought stress on antioxidant enzymes activity of some chickpea cultivars. American-Eurasian J. Agric. Environ. Sci. 11(6): 782-785.

Mohanty S., Parida R., Sandeep I.S., Sahoo S., NAYAK S., 2015. Evaluation of drug yielding potential of micropropagated Curcuma aromatica. J. Pharm. Pharmacol. 7(4): 71-76.
Moon T., Cavanagh H.M.A., Wilkinson J.M., 2007. Antifungal activity of Australian grown Lavandula spp. essential oils against Aspergillus nidulans, Trichophyton mentagrophytes, Leptosphaeria maculans and Sclerotinia sclerotiorum. J. Essent. Oil Res. 19(2): 171-175.

Murashige T., Skoog F., 1962. A revised medium for rapid growth and bioassays with tobacco tissue cultures. Physiol. Plant. 15: 473-497.

NaIdu A.C., ShaH G.L., 1981. Observation on the cotyledonary stomata and trichomes and their ontogeny in some genera of Lamiaceae. Phyton (Austria) 21(1): 137-152.

Niculae M., Spînu M., Şandru C.D., BrudaşCă F., Cadar D., Szakacs B., Scortu I., Bolfă P., Mateş C.I., 2009. Antimicrobial potential of some Lamiaceae essential oils against animal multiresistant bacteria. Lucrări Ştinłifice Medicină Veterinară. XLII(1): 170-175.

NiKolova M., 2011. Screening of radical scavenging activity and polyphenol content of Bulgarian plant species. Pharmacognosy Res. 3(4): 256-259.

Nitzsche A., ToKalov S.V., Gutzeit H.O., LudwingMüller J., 2004. Chemical and biological characterization of cinnamic acid derivates from cell cultures of lavender (Lavandula officinalis) induced by stress and jasmonic acid. J. Agric. Food Chem. 52: 2915-23.

Nogueira J.M., Romano A., 2002. Essential oils from micropropagated plants of Lavandula viridis. Phytochem. Anal. 13(1): 4-7.

Parkash V., Singh H., 2013. Lavandula angustifolia L. (Lavender): An important aromatic medicinal shrub and its in vitro micro-propagation for conservation. IJAT 9(3): 691-702.

Prabuseenivasan S., Jayakumar M., Ignacimuthu S., 2006. In vitro antibacterial activity of some plant essential oils. BMC Complement Altern. Med. 6(39): 1-8.

Prasad A., Shukla S.P., Mathur A., Chanotiya C.S., Mathur A.K., 2015. Genetic fidelity of long-term micropropagated Lavandula officinalis Chaix.: an important aromatic medicinal plant. Plant Cell Tiss. Organ. Cult. 120(20): 803-811.

Proestos C., Boziaris I.S., Nychas G.J.E., Komaitis M., 2006. Analysis of flavonoids and phenolic acids in Greek aromatic plants: Investigation of their antioxidant capacity and antimicrobial activity. Food Chem. 95: 664-671.

Proestos C., Lytoudi K., Mavromelanidou O.K., Zoumpoulakis P., Sinanoglou V.J., 2013. Antioxidant capacity of selected plant extracts and their essential oils. Antioxidants 2: 11-22.

Rapper S., Kamatou G., Viljoen A., Vuuren S., 2013. The in vitro antimicrobial activity of Lavandula angustifolia essential oil in combination with other aroma-therapeutic oils. Evid. Based Complement. Alternat. Med. 852049: 1-10. 
Re R., Pellegrini N., Proteggente A., Pannala A., Yang M., Rice-Evans C., 1999. Antioxidant activity applying an improved ABTS radical cation decolorization assay. Free Radic. Biol. Med. 26(910): 1231-1237.

Robu S., Aprotosoaie A.C., Miron A., Cionnca O., Stanescu U., Hancianu M., 2012. In vitro antioxidant activity of ethanolic extracts from some Lavandula species cultivated in Romania. Farmacia 60(3): 394-401.

Rota C., Carramiñana J.J., Burillo J., Herrera A., 2004. In vitro antimicrobial activity of essential oils from aromatic plants against selected foodborne pathogens. J. Food Prot. 67(6): 1252-1256.

RyU S.B., WANG X., 1998. Increase in free linolenic and linoleic acids associated withphospholipase D-mediated hydrolysis of phospholipids in wounded castor bean leaves. Biochim. Biophys. Acta. 1393(1): 193-202.

Sakamoto R., Minoura K., Usui A., Ishizuka Y., Kanba S., 2005. Effectiveness of aroma on work efficiency: Lavender aroma during recesses prevents deterioration of work performance. Chem. Senses 30: 683-691

Sheena E.V., Jотні G.J., 2015. Comparative phytochemical screening and antioxidant properties of in vitro and in vivo propagated Orthosiphon stamineus Benth (Lamiaceae). Asian J. Pharm. Clin. Res. 8(4): 216-220

Silva G.L., Luft C., Lunardelli A., Amaral R.H., DA Silva Melo D.A., Donadio M.V., 2015. Antioxidant, analgesic and anti-inflammatory effects of lavender essential oil. An. Acad. Bras. Cienc. 87(2): 1397-408.

Skala E., Kalemba D., WaJs A., Różalski M., KrajewsKa U., RóżalsKa B., 2007. In vitro propagation and chemical and biological studies of the essential oil of Salvia przewalskii Maxim. Z. Naturforsch. C 62(11-12): 839-848.

Soni D.R., Sodhi G.K, SAyyad F.G., 2013. Micropropagation studies in Lavandula angustifolia. Discovery Biotechnology 4(12): 34-37.

Spiridon I., Colceru S., Anghel N., Teaca C.A., Bodirlau R., Armatu A., 2011. Antioxidant capacity and total phenolic contents of oregano (Origanum vulgare), lavender (Lavandula angustifolia) and lemon balm (Melissa officinalis) from Romania. Nat. Prod. Res. 25(17): 1657-1661.

Stanojević L., Stanković M., Cakić M., Nikolić V., Nikolić L., Ilić D., Radulović N., 2011. The effect of hydrodistillation techniques on yield, kinetics, composition and antimicrobial activity of essential oils from flowers of Lavandula officinalis L. Hemijska Industrija 65(4): 455-463.

Stehfest K., Boese M., Kerns G., Piry A., Wilhelm C., 2004. Fourier transform infrared spectroscopy as a new tool to determine rosmarinic acid in situ. J. Plant Physiol. 161: 151-156.
Sudriá C., Piñol M.T., Palazon J., Cusido R.M., Vila R., Morales C., Bonfill M., Canigueral S., 1999. Influence of plant growth regulators on the growth and essential oil content of cultured Lavandula dentata plantlets. Plant Cell Tiss. Org. Cult. 58: 177184.

Sudriá C., Palazón J., Cusidó R., Bonfill M., Piñol M.T., Morales C., 2001. Effect of benzyladenine and indolebutyric acid on ultrastructure, glands formation, and essential oil accumulation in Lavandula dentata plantlets. Biol. Plant. 44: 1-6.

Śmigielski K., Raj A., Krosowiak K., Gruska R., 2009. Chemical composition of the essentials oil of Lavandula angustifolia cultivated in Poland. J. Essent. Oil Bear. Plants 12(3): 338-347.

TAHA R.M., Haron N.W., 2008. Some morphological and anatomical studies of leaves and flowers of Murraya paniculata (Jack) Linn. in vivo and in vitro. Pak. J. Biol.Sci.11: 1021-1026.

Thosar N., BASAK S., Bahadure R.N., Rajurkar M., 2013. Antimicrobial efficacy of five essential oils against oral pathogens: An in vitro study. Eur. J. Dent. 7(1): 71-77.

Turner G.W., Croteau R., 2004. Organization of monoterpene biosynthesis in Mentha. Immunocytochemical localizations of geranyl diphosphate synthase. limonene-6-hydroxylase, isopiperitenol dehydrogenase, and pulegone reductase. Plant Physiol. 136(4): 4215-4227.

Uniyal V., Bhatt R.P., Saxena S., Talwar A., 2012. Antifungal activity of essential oils and their volatile constituents against respiratory tract pathogens causing Aspergilloma and Aspergillosis by gaseous contact. J. App. Nat. Sci. 4 (1): 65-70.

Upson T., Andrews S., 2004. The genus Lavandula. Timber Press. Inc., USA.

Valizadeh S., Fakheri T., Mahmoudi R., Katiraee F., Ghajarbeyg P., 2015. Phytochemical and antimicrobial properties of Lavender angustifolia and Eucalyptus camaldulensis essential oils. J. Food Saf. Hyg. 1(2): 8-14.

Verma R.S., Rahman L.U., Chanotiya C.S., Verma R.K., Chauhan A., Yadav A., Singh A., Yadav A.K., 2010. Essential oil composition of Lavandula angustifolia Mill. cultivated in the mid hills of Uttarakhand, India. J. Serb. Chem. Soc. 75: 343-348.

Vidwans H., Moghe R., Upadhyay A., 2015. Invitro micropropagation and comparative study on antimicrobial activity of micropropagated and naturally growing plants of Syzygium cumini. Internat. J. Environ. Sci. 6(2): 301-306.

Werker E., Ravid U., Putievsky E., 1985. Structure of glandular hairs and identification of the main components of their secreted material in some species of the Labiatae. Isr. J. Bot. 34: 31-45.

Wesolowska A., Grzeszczuk M., Kulpa, D., $2015 a$. GC-MS analysis of the essential oil from flowers of Chrysanthemum coronarium L. propagated 
conventionally and derived from in vitro cultures. Acta Chromatogr. 27(3): 525-539.

Wesolowska A., Grzeszczuk M., Kulpa D., 2015 b. Propagation method and distillation apparatus type affect essential oil from different parts of Matricaria recutita L. plants. J. Essent. Oil Bear. Plants 18(12): 179-194.

Wojdylo A., Oszmiański J., Czemerys R., 2007. Antioxidant activity and phenolic compounds in 32 selected herbs. Food Chem. 105: 940-949.

Woronuk G., Demissie Z., Rheault M., Mahmoud S., 2011. Biosynthesis and therapeutic properties of
Lavandula essential oil constituents. Planta Med. 77(1): 7-15.

Zuzarte M., Dinis A.M., Cavaleiro C., Canhoto J., SAlgueiro L., 2008. Trichomes morphology and essential oils characterization of field-growing and in vitro propagated plants of Lavandula pedunculata. Microsc. Microanal. 14(3): 148-149.

Zuzarte M.R., Dinis A.M., Cavaleiro C., Salgueiro L.R., CANHOtOA J.M., 2010. Trichomes, essential oils and in vitro propagation of Lavandula pedunculata (Lamiaceae). Ind. Crop. Prod. 32: 580-587.

Received April 22, 2017; accepted August 1, 2017 